\title{
Financial Reporting Frequency and Managerial Learning from Stock Price
}

\begin{abstract}
Using hand-collected data on changes in public firms' financial reporting frequency over the peirod 1951-1974, we provide evidence that increased reporting frequency enhances the extent to which stock price guides managers' investment decisions. Using a generalized differencein-differences research design, we find the sensitivity of investment to stock price (measured by Tobin's $Q$ ) increased for treatment firms following an increase in reporting frequency, relative to control firms. The results are more pronounced among firms traded by more informed investors, measured by price nonsynchronicity and stock illiquidity. Consistent with managers making better investment decisions when stock prices provide more investment-relevant information, we find future operating performance of the treatment firms improves following the increase in reporting frequency. Our findings are consistent with the "crowding-in effect" theorized in Goldstein and Yang (2019). Our results are relevant to the ongoing regulatory debates in the United States and European Union regarding how frequently firms should be required to report their financial results.
\end{abstract}

Keywords: Financial reporting frequency; managerial learning; price informativeness. JEL Classification: M40; M41; G31. 


\section{Introduction}

An important aspect of any financial reporting framework is how frequently firms are mandated to report their financial statements. Mandatory reporting frequency is an important but difficult regulatory design choice because it fundamentally affects the information environment for publicly traded firms. The difficulty in determining the optimal reporting frequency occurs because reporting frequency affects the incentives of numerous market participants, including analysts, investors, creditors, competitors, as well as managers, in diverse and often imperfectly understood ways. Not surprisingly, financial reporting frequency has been a controversial issue subject to much policy debate globally. For example, the European Union recently removed an earlier requirement for quarterly reporting while the Unites States is currently considering whether to reduce reporting frequency. Analyzing the effects of financial reporting frequency is difficult because there are relatively few research settings where reporting frequency varies across firms or across time. Thus, the literature on financial reporting frequency is relatively undeveloped. We add to this literature by examining how reporting frequency affects managers' ability to learn investment-related information from their stock prices.

We assume that managers use all available information when making their investment decisions, including any information about current or future investment opportunities that are embedded in stock prices. Managers know much of the firm-specific information in stock prices. However, prices also reflect how industry- and macro-level information relates to their firm and managers are relatively less informed about this type of information Hutton et al. (2012). ${ }^{1}$ To the extent stock prices incorporate information about the firm's investment opportunities that is new to managers, they can learn valuable information about the value of their firm's investment

\footnotetext{
${ }^{1}$ For example, Hutton et al. (2012) show that financial analysts enjoy a comparative advantage over managers in macro information.
} 
opportunities from stock prices (Bakke and Whited 2010; Chen et al. 2007, 2017; Edmans et al. 2017; Foucault and Fresard 2012; Jayaraman and Wu 2019).

The degree to which more frequent financial reporting changes the investment usefulness of stock prices depends on how it affects the private information search activities of informed investors and information intermediaries, such as analysts and the press (Demski and Feltham 1994; Kim and Verrecchia 1991; McNichols and Trueman 1994; Verrecchia 2001). Goldstein and Yang (2019) analytically show that when firms publicly disclose more information that the manager is already aware of, it increases investors' incentives to acquire types of private information that are unknown to the manager (i.e., the two types of information are substitutes). Since managers are already knowledgeable about the information contained in the financial reports, we predict the investment usefulness of stock prices increases following an increase in reporting frequency.

To provide evidence on this important issue, we examine changes in U.S. firms' financial reporting frequency over the period 1951-1974. During this period, the Securities and Exchange Commission (SEC) first increased the mandatory reporting frequency from annual to semi-annual in 1955 and then from semi-annual to quarterly in 1970. While most firms had voluntarily increased their reporting frequency prior to these actions, there were a substantial number of mandatory adopters that did not increase their reporting frequency until mandated by the SEC. While dated, this setting provides a powerful setting to examine the effects of changes in reporting frequency (Butler et al. 2007; Fu et al. 2012; Kraft et al. 2018).

We use investment-to-price sensitivity (hereafter, IPS) to measure the degree to which managers learn new information about the value of their investment opportunities from stock prices (Bakke and Whited 2010; Chen et al. 2007; Edmans et al. 2017; Foucault and Fresard 2012; Jayaraman and Wu 2019). In our primary empirical tests, we examine how increased reporting 
frequency affects IPS for treatment firms relative to control firms that did not change reporting frequency in a generalized difference-in-differences framework where Tobin's $Q$ is used to measure stock price. Consistent with prior literature, we measure investments using (1) one-yearahead change in property, plant, and equipment and (2) one-year-ahead capital expenditure.

Our primary results indicate IPS significantly increased for treatment firms following the increase in reporting frequency compared to control firms. Further tests indicate the increase in reporting frequency resulted in long-lasting increases in IPS as the effects are significant for at least five years following the increase in reporting frequency. The results are economically significant as well. Thus, consistent with our hypothesis, the evidence indicates managers of treatment firms behaved as if their stock prices contained more information about investment opportunities when they made their investment decisions during the post-adoption period. ${ }^{2}$

We expect our results are driven the "crowding-in" effect developed in Goldstein and Yang (2019), whereby more frequent financial reports (of which mangers already know) incentivizes sophisticated investors to search for more private information that is unrelated to the financial reports. In which case, we expect the effects of reporting frequency on IPS will be concentrated among treatment firms that experience the greatest increase in informed trading. Following prior literature (Chen et al. 2007; Jayaraman and Wu 2019), we use stock price nonsynchronicity $\left(1-\mathrm{R}^{2}\right)$ and the Amihud's (2002) stock illiquidity to proxy for the amount of trading by informed investors, and by extension, the amount of private investment-relevant

\footnotetext{
${ }^{2}$ An alternative explanation for our results is the financial constraints channel posited by (Baker et al. 2003). They find investment-to-price sensitivity is stronger for financially constrained firms who depend on equity financing to fund their investments. In other words, investment varies with stock price because higher (lower) stock prices increase (decrease) their ability to fund investments. The financial constraints channel predicts higher IPS among more equitydependent firms. If treatment firms are more financially constrained and increasing reporting frequency increases stock prices by reducing the cost of capital (Fu et al. 2012), then our results could be due to the financial constraints channel. However, we find the increase in IPS is driven by less equity-dependent firms, who can more easily adjust their investment levels in response to new information (Chen et al. 2007; Edmans et al. 2017).
} 
information incorporated in stock prices. Our results show the increase in the IPS is among firms with more trading based on private-information. Thus, our evidence is consistent with the prediction in Goldstein and Yang (2019) such that more frequent financial reporting leads to more informed trading, which in turns increases the usefulness of stock prices to managers' investment decisions.

One implication of the prior results is that managers at treatment firms will have made relatively more informed investment decisions after the increase in reporting frequency given additional investment-related information available in stock prices. In which case, we expect the future operating performance of treatment firms will be enhanced relative to control firms as they make better investment decisions. Consistent with this implication, we find future operating performance over the following one, two, and three years is significantly higher for treatment firms following their increase in reporting frequency relative to control firms. Thus, our results indicate a real effect of reporting frequency on the quality of firms' investment decisions.

We contribute to extant literature in three primary ways. First, we contribute to relatively undeveloped literature that examines the costs and benefits of financial reporting frequency. Kothari et al. (2010) argues that efficient capital allocation is (or at least should be) the ultimate aim of financial reporting. By this measure, prior literature has provided mixed evidence on the desirability of mandating quarterly financial reporting relative to semi-annual reporting. While $\mathrm{Fu}$ et al. (2012) and to a lesser extent Butler et al. (2007) find evidence consistent with more frequent reporting increasing the information content of stock prices, the results in Kraft et al. (2018) and Fu et al. (2019) suggests quarterly reporting reduces allocational efficiency. We contribute to this literature by examining how reporting frequency affects the amount of new investment-related information that managers can learn from stock prices - a construct that is directly related to 
allocational efficiency. We find that higher reporting frequency indirectly leads to better informed investment decisions by managers.

Second, we contribute to the investment-price sensitivity literature that provides evidence of a causal link between changes in the informativeness of stock prices and changes in investmentprice sensitivity (Edmans et al. 2017; Foucault and Frésard 2012; Jayaraman and Wu 2018). In our setting, we find managers' reliance on stock prices when making investment decisions increases following an increase in financial reporting frequency. Given that managers are already aware of the information disclosed in their own firm's financial statements, these disclosures are not expected to directly increase the investment-related information in stock prices. Instead, our results indicate that the increase in public disclosures leads to an increase in private information search activity, which in turn increases the investment relevant information in prices. As such, our results are consistent with the theoretical prediction in Goldstein and Yang (2019). ${ }^{3}$

Third, we contribute to the broader literature that examines the costs and benefits of mandated public information disclosures. We document positive informational effects for financial markets, and consequently managers' investment decisions, following an increase in reporting frequency. Our findings suggest that mandating the disclosure of information already known by managers can ultimately benefit firms by providing managers with new information about the firm's investment opportunities. Our results indicate increasing reporting frequency shifted the distribution of private information search activities towards (away from) private information that was new to managers (public information that was known to managers). This result is in contrast to previous studies documenting a substitution effect between public disclosures and private

\footnotetext{
${ }^{3}$ Jayaraman and $\mathrm{Wu}$ (2019) find a reduction in IPS following a mandatory increase in segment reporting disclosures. They interpret their results as indicating increased disclosure reduced investors' incentives to acquire private information that would be useful to managers. Thus, their results are only consistent with the prediction in Goldstein and Yang (2019) segment-related disclosures are compliments to managers' information sets, rather than substitutes.
} 
information search activities (Brown and Hillegeist 2007; Healy et al. 1999; Welker 1995). As such, our findings highlight the importance of understanding how different types of disclosures differentially affect private search activities (Edmans et al. 2017; Goldstein and Yang 2019).

Overall, our evidence adds to our understanding of the nuanced effects of financial reporting frequency on investors' information search decisions and managerial learning from stock prices. Accordingly, our paper has implications for regulators in the U.S. and Europe as they continue to debate the merits of quarterly reporting. The evidence in our paper suggests the recent decision by both the EU and the U.K. to abandon the mandatory quarterly reporting requirement could have reduced the ability of managers to learn information about their investment opportunities from stock prices - a previously unexplored benefit of more frequent reporting.

The paper is organized as follows. Section 2 discusses institutional background related to financial reporting frequency in the U.S. and develops our hypothesis. Section 3 describes our data, sample, and research design. Section 4 presents our empirical findings, while the conclusion is in Section 5 .

\section{Institutional Background and Hypothesis Development}

\subsection{Institutional Background}

Before the Securities Act of 1933 and Securities Exchange Act of 1934 (Securities Acts), financial reporting was primarily governed by stock exchanges. The New York Stock Exchange (NYSE), in particular, began requiring some newly listed firms to periodically report profit and balance sheet information around the turn of the century, and by 1923, required all newly listed firms to publish quarterly financial statements. The American Stock Exchange (AMEX) and regional exchanges did not take similar steps until the early 1960s (Taylor 1963). The SEC took an active role in regulating reporting frequency for exchange-listed firms starting with the 
Securities Exchange Act of 1934, which mandated annual reporting in 1934, continuing with semiannual reporting in 1955, and finally mandating quarterly reporting in 1970.

Beyond these mandatory requirements, the NYSE pressured already-listed companies to publish quarterly reports. In both 1926 and 1931, the NYSE approached all companies that had not already agreed to report quarterly, asking them to amend their listing agreements to include this reporting frequency requirement (NYSE, 1939). ${ }^{4}$ These efforts were reasonably successful as the percentage of NYSE firms reporting quarterly (semi-annually) increase from $25 \%$ to $37 \%$ ( $8 \%$ to $15 \%$ ) in 1927 and further increased to 63\% (17\%) in 1932 (NYSE, 1939). By the mid-1950s (1962), the NYSE's efforts were mostly successful, as $89.5 \%$ (95\%) of the active domestic companies on the NYSE were publishing earnings reports quarterly (Taylor 1963). ${ }^{5}$

In contrast to the NYSE, the AMEX nor the regional exchanges were uniformly opposed to mandating more frequent reporting and repeatedly opposed all related SEC proposals to do so. ${ }^{6}$ This opposition appeared to be motivated by a concern that some firms, finding the regulations too burdensome, might choose to delist and trade over the counter. Additionally, a quarterly reporting regime for all listed firms would mean less differentiation between the NYSE and non-NYSE exchanges, leaving fewer reasons for firms not to move to the NYSE.

In later years, the AMEX and the other exchanges softened their stance and also adopted requirements that newly listed corporations report on a quarterly basis. The AMEX adopted this requirement for new firms starting in 1962, and also sent a letter to all listed companies with the

\footnotetext{
${ }^{4}$ In 1939, the NYSE published an article entitled "Exchange Encourages Interim Financial Reports" in the New York Stock Exchange Bulletin, vol. X, no. 8 (August 1939). This article reports the progress made by the NYSE in getting firms to report quarterly, including the efforts it undertook during the 1920s.

${ }^{5}$ Letter dated March 7, 1955 to the SEC from G. Keith Funston, President of the NYSE (Taylor 1963).

${ }^{6}$ For example, in response to an SEC proposal in 1955 requiring companies to report semi-annually, the president of the AMEX, Edward McCormick, sent a letter dated February 28, 1955 to the SEC firmly opposing this measure. (Taylor 1963).
} 
new requirements asking them to report quarterly if they did not already do so. ${ }^{7}$ However, not all AMEX companies complied with this request.

In 1945, the SEC took steps to have companies report their financial information more frequently than annually (see Figure 1 for a timeline of the SEC's actions). The move toward more frequent reporting stemmed from the SEC's concern that firms whose sales were dominated by war contracts would have large reductions in business and that investors might be caught off-guard. In July 1945, the SEC adopted a rule requiring firms with war business in excess of $25 \%$ of sales in the prior year to file a quarterly report using the form $8-\mathrm{K}$, containing total sales, sales made pursuant to war contracts, and unfilled orders. ${ }^{8}$ In 1946, the SEC adopted a rule requiring all firms to report revenues on a quarterly basis, with exceptions for certain industries. ${ }^{9}$ Although the SEC preferred that firms report income along with the sales information, it ultimately did not include this as a requirement, apparently acquiescing to public criticisms that quarterly income information would be unreliable and potentially misleading due to the seasonal nature of some businesses.

In the early 1950s, the SEC wavered on requiring quarterly reporting. It first proposed quarterly reporting of income information, then abandoned the proposal, and later rescinded even its quarterly sales reporting requirements before finally mandating semi-annual reporting of income. Proposed in January 1955 and adopted in June of that year, the switch to semi-annual reporting required firms to provide semi-annual reports within 45 days of the end of the first half of the fiscal year. ${ }^{10}$ Firms were required to report sales, net income (before and after taxes), and all extraordinary and special items.

\footnotetext{
${ }^{7}$ American Stock Exchange, Listing Standards, Policies and Requirements (New York: The Exchange, 1962, 3) (Taylor 1963).

${ }^{8}$ SEC, Securities Exchange Act of 1934, Release No. 3718, July 23, 1945.

${ }^{9}$ SEC, Securities Exchange Act of 1934, Release No. 3803, March 28, 1946.

${ }^{10}$ See SEC, Securities Exchange Act of 1934, Release No. 5129, January 27, 1955 for proposal and SEC, Securities Exchange Act of 1934, Release No. 5189, June 23, 1955 for adoption.
} 
The SEC did not reconsider quarterly reporting until the end of the 1960 s when the Wheat Commission proposed it. As a result, in September 1969, the SEC proposed that companies be required to file quarterly reports on a new Form 10-Q. The proposal was adopted in October 1970. ${ }^{11}$ Thereafter, firms had to report detailed profit and loss information, earnings per share, and information on the issuer's capitalization and shareholders' equity. The rule went into effect for fiscal quarters ending after December 31, 1970, although a few select industries such as life insurance companies and public utilities were exempt from the requirement.

\subsection{Hypothesis Development}

How mandatory disclosures in general, and financial reporting frequency in particular, affect the information environment depends on whether and how they affect the production of additional private information by various market participants. Identifying these information production effects and how they interact with each other is especially complex because accounting reports can either act as substitutes or complement to information produced by market participants and sometimes both at the same time. For example, consider how the release of financial statements can affect the information production activities of analysts. To the extent that analysts are concerned with near-term forecasting activities, then more frequent financial reporting will act as a substitute for analysts' reports. By releasing more of the managers' private information about upcoming earnings, more frequent reporting reduces information asymmetry about future earnings, and hence, the demand for earnings forecasts by analysts (Healy and Palepu 2001). In contrast, more frequent reporting can complement work done by analysts through reducing the cost of forecasting earnings (Bhushan 1989a, 1989b; Lang and Lundholm 1993). These cost reductions

\footnotetext{
${ }^{11}$ SEC, Securities Exchange Act of 1934, Release No. 8683, October 15, 1969 and SEC, Securities Exchange Act of
} 1934, Release No. 9004, October 28, 1970. 
can enabling analysts to improve stock recommendations by focusing on how industry and market developments will affect future earnings growth and risk. ${ }^{12}$

Prior empirical research shows that financial reporting frequency affects firms' information environments in several ways, including the information content of annual reports (McNichols and Manegold 1983), earnings timeliness (Alford et al. 1993; Butler et al. 2007), and real earnings management (Ernstberger et al. 2017). These changes in the information environment will affect the information search activities of large, sophisticated investors (including institutional investors, short sellers, and hedge funds) by changing the costs and benefits of searching for private information as well as types of private information they search for. As discussed below, whether the net effect of all of these changes in private information search activities is to increase or decrease the investment-related information in stock prices is theoretically ambiguous (Edmans et al. 2015; Goldstein and Yang 2015, 2019).

Managers do not have perfect information about their firms' growth or investment opportunities (Bond et al. 2012). Managers who attempt to maximize expected firm value will use all information available to them when making corporate investment decisions. One source of investment-relevant information is the firm's stock price. Stock price aggregates public and private information from the trading activity of diverse investors (Dow and Gorton 1997; Grossman and Stiglitz 1980). Thus, stock prices reflect at least some private information that is otherwise unknown to managers. Managers can achieve a more efficient allocation of corporate resources,

\footnotetext{
${ }^{12}$ A mandatory increase in financial reporting frequency can reduce voluntary disclosures by the firm due to an increase in the overall cost of disclosure (including production and dissemination costs, legal costs, and proprietary costs or a reduction in the benefit of each additional disclosure (Gigler and Hemmer 1998, 2001). Also see (Einhorn 2005). Thus, changes in voluntary disclosures can offset some of the effects of the increase in reporting frequency.
} 
and hence, a higher firm value, by incorporating this new (to the manager) information into their investment decisions (Bond et al. 2012; Chen et al. 2007; Edmans et al. 2017). ${ }^{13}$

The degree to which managers can learn about the value of their investment opportunities from stock prices depends on the extent to which managers and informed investors have different types of private information. Typically, managers are expected to have superior information about internal firm conditions while outside investors are more informed about industry and macroeconomic conditions. Both types of information are relevant for making investment decisions. The extent to which the manager relies on stock prices to make investment decisions directly depends on the extent to which outside investors search for and trade on private information that is both relevant to the firm's investment decisions and unknown to the manager (Edmans et al. 2017). For example, if outside investors search for and trade on private information about upcoming earnings, these activities are unlikely to provide the manager with new information about the firm's investment opportunities. In contrast, search activities focused on how developments at competitors, suppliers, or customers will affect the firms are likely to produce private information that is both new to the manager and highly relevant to her investment decisions. Not all private information in stock prices increases the extent to which price reveals new investment relevant information to managers (Bond et al. 2012; Dow and Gorton 1997; Edmans et al. 2017; Jayaraman and Wu 2019).

In summary, whether more frequent financial reporting leads to an increase in IPS depends on whether informed investors (and market participants in general) increase or decrease the search

\footnotetext{
${ }^{13}$ The following is a real-world example of managers learning from stock prices that is cited in Edmans et al. (2015, 3767): "A classic example of how information from the stock market can shape real decisions is Coca-Cola's attempted acquisition of Quaker Oats. On November 20, 2000, the Wall Street Journal reported that Coca-Cola was in talks to acquire Quaker Oats. Shortly thereafter, Coca-Cola confirmed such discussions. The market reacted negatively, sending Coca-Cola's shares down 8 percent on November 20 and 2 percent on November 21. Coca-Cola's board rejected the acquisition later on November 21, potentially due to the negative market reaction. The following day, Coca-Cola's shares rebounded 8 percent".
} 
activities for private investment-related information that is new to managers. One possible outcome is that more frequent reporting crowds out informed trading, thereby reducing the amount of private investment-related information impounded in stock prices. Another possible outcome is that more frequent reporting causes investors to focus their search activities on private investmentrelated information that is new to managers. Goldstein and Yang (2019) develop a model to analyze how the type of information the firm publicly discloses affects investors' search activities, and hence, whether IPS increases or decreases.

The key finding in Goldstein and Yang (2019) is that the net effect depends on whether the public disclosure is about information that the manager (outside investors) is relatively more informed about. In the first case, the manager makes a disclosure about information that they know with higher precision than outside investors. This disclosure causes investors focus their search activities on other types of information about which the manager has relatively less precise information. In this case, the search activities cause more information that is new to the manager to be incorporated into stock prices (and hence, increases IPS). In the second case, the manager makes a disclosure about information that they know with relatively lower precision. This type of disclosure causes investors to focus their search activities on private information that the manager already knows with high precision (and hence, decreases IPS). ${ }^{14}$

We expect managers have the most precise information about the information disclosed in interim financial reports for two reasons. First, managers have superior information about internal firm conditions, and it is these conditions that are reflected in the interim financial statements.

\footnotetext{
14 Jayaraman and Wu (2019) find IPS decreases after firms are required to make new segment disclosures. They interpret segment disclosures are related to segment-level competition, which is a type of information about which managers are relatively less informed. As a consequence, investors focus their search activities on information that the manager is relatively more informed. Thus, their search activities reduce the amount of new investment-related information in stock prices. In which case, their results are consistent with the prediction in Goldstein and Yang (2019).
} 
Second, the information contained in the reports is unlikely to represent new information to the manager because this type of information is generated internally to manage the business even when it is not required to be disclosed. Thus, we expect that more frequent financial reporting reflects more precise public information that managers already know, and hence, our setting corresponds to the first case in Goldstein and Yang (2019). Accordingly, we make the following hypothesis (in alternative form):

Hypothesis: The sensitivity of corporate investment to stock price increases when the frequency of financial reporting increases.

\section{Data, Sample, and Research Design}

\subsection{Data and Sample}

The data employed in this paper comes from various sources. We use Compustat for accounting data and CRSP for stock and liquidity data. Data on the financial reporting frequency is obtained from Butler et al. (2007). Reporting frequency data was collected by them from Moody's Industrial News Reports (refer to Butler et al. (2007) for further details about data composition and original sample). We use reporting frequency data to derive two samples of treatment firms matched with equal number of control firms. The first sample of treatment firms includes all firms that voluntarily or involuntarily increased their reporting frequency (i.e., the full sample). The second sample only consists of firms that involuntarily increased their reporting frequency (i.e., the mandatory sample). The mandatory sample consists of firms that increased their reporting frequency because of the two SEC mandates by the SEC in years 1955 and 1970 or due to pressure by the AMEX to report on a quarterly basis around year 1962. Following Kraft et al. (2018), we define treatment firms as the firms that did not change the reporting frequency during the two-year period prior to the treatment year. The final number of full (mandatory) sample is 886 (492). Table 1, Panel A reports the distribution of treatment firms that increased reporting 
frequency for both samples. Full sample also include firms that voluntarily increased their reporting frequency to three times per year.

The set of possible control firms consists of all firms that did not change reporting frequency during the five years around the treatment year (i.e., $(-2,+2)$, where year 0 is the treatment year). We identify a matched control sample using propensity score matching's nearest neighbour matching technique. To ensure high quality matching, observations that fall outside the common support are dropped (Smith and Todd 2005). In every treatment firm-year, we match our treatment firms with control firms based on firm size, sales growth, leverage, profitability, and industry (i.e., Fama-French twelve industry classification). Sales growth proxies for growth opportunities (Shin and Stulz 1998; Whited 2006; Badertscher et al. 2013); size, profitability, and leverage proxy for the availability of financing to engage in investment (Kaplan and Zingales 1997; Hadlock and Pierce 2010). We match relatively broadly on industry due to sample attrition issues, however, as discussed below, our regression specifications include industry-year interactive effects, which fully account for the effect of any time-varying industry differences across firms (Gormley and Matsa 2014).

Table 1, Panel B presents the mean values of the variables used for matching. As can be seen, the treatment and control firms are almost identical on these dimensions. T-tests for differences in the mean levels of firm size, sales growth, profitability, and leverage across treatment and control firms in the treatment year show that we are unable to reject the null hypothesis of equal means. Thus, our matching procedure appears to yield satisfactory matching quality for reliable inferences.

We provide additional descriptive statistics for the full and mandatory samples in Panels A and B of Table 2, respectively. By construction, the size of the full sample is substantially larger 
than the size of the mandatory sample (11,364 firm-year observations vs. 6,180 firm-year observations). Comparing the descriptive statistics across the two samples, the mean and median values are very similar.

Table 3 tabulates the correlations between our primary variables. As expected, our two measures of investment are highly correlated ( 0.789 and 0.786 for the full and mandatory samples, respectively). In addition, $Q$ is positively associated with future investments (correlations are between 0.18 and 0.20 ), which is consistent with stock prices being positively associated with future investment opportunities.

\subsection{Research Design}

The sensitivity of managers' investment decisions to their firm's stock price (IPS) is commonly interpreted as the extent to which managers learn new private information about the value of their firm's investment opportunities from stock prices (Bakke and Whited 2010; Chen et al. 2007; Edmans et al. 2017; Foucault and Fresard 2012, 2014; Jayaraman and Wu 2019). Accordingly, we test our main hypothesis using a difference-in-differences approach that compares changes in IPS before versus after the increase in reporting frequency of treatment firms. The design is similar to prior research in this area (Edmans et al. 2017; Foucault and Fresard 2012; Jayaraman and $\mathrm{Wu}$ 2019). Specifically, we estimate the following difference-in-differences regression to test our predictions:

$$
\begin{aligned}
y_{i, t+1} & =\alpha_{i}+\alpha_{t} \times \alpha_{i n d}+\beta_{1} Q_{i, t}+\beta_{2} T R E A T \times Q_{i, t}+\beta_{3} P O S T \times Q_{i, t}+\beta_{4} T R E A T \times P O S T \times Q_{i, t} \\
& +\beta_{5} \text { TREAT } \times P O S T_{i, t}+\beta_{6} P O S T_{i, t}+\beta_{7} P O S T \times C F_{i, t}+\beta_{8} T R E A T \times P O S T \times C F_{i, t}+\beta_{9} C F_{i, t} \\
& +\beta_{10} S I Z E_{i, t}+\beta_{11} L_{E V E R A G E_{i, t}}+\beta_{12} S A L E S G R O W T H_{i, t}+\beta_{13} \text { LIQUIDITY }_{i, t}+\varepsilon_{i, t}
\end{aligned}
$$


where $i$ ( $t$; ind $)$ indexes firms (years; industry), $y_{i, t+1}$ is one year ahead change in investment (CHG_PPE or CAPEX) ${ }^{15} \alpha_{i}, \alpha_{t}$, and $\alpha_{\text {ind }}$ are firm, year, and industry fixed effects, respectively. $Q$ is Tobin's $\mathrm{Q}$, which is calculated as market value of assets divided by book value of assets. TREAT is an indicator variable that equals one for treatment firms, and zero otherwise. POST is an indicator variable that equals one for years after the treatment year, and zero otherwise. As in (Kraft et al. 2018), we include data for up to five years before and after the treatment year, i.e., ($5,+5$ ) for our sample firms (both treatment and control) excluding the treatment year (0). Since $Q$ is a price-based measure of investment opportunities, we also include a non-price-based measure, $C F$ (cash flows) in our regression specification as a benchmark. Other time-varying control variables include firm size, leverage, sales growth, and liquidity. We cluster standard errors by firm. Variable definitions are provided in the Appendix.

As Kraft et al. (2018) discuss, our results setting has certain features which serve to mitigate concerns that our results could be driven by contemporaneous changes in growth opportunities. In addition to the difference-in-differences design and various controls for time-varying factors and firm characteristics related to growth opportunities, the timing of reporting frequency increases is determined exogenously and the shocks to reporting frequency changes are staggered in time. Thus, our research setting and design is robust and allows us to make relatively precise make causal inferences about any changes in IPS for treatment firms after increases in reporting frequency.

Our main coefficient of interest in Equation (1) is the $\beta_{4}$ coefficient on the interaction term $T R E A T \times P O S T \times Q_{i, t}$, which captures the effect of reporting frequency increases on IPS for

\footnotetext{
${ }^{15}$ Other studies investigating IPS frequently use R\&D expenditures as an additional measure of investment. However, we are unable to analyze $R \& D$ expenditures due to data constraints.
} 
treatment firms relative to contemporaneous changes for control firms. Under our hypothesis, we expect the sign of $\beta_{4}$ to be positive and significant.

\section{Main Results}

In this section, we present our main empirical results. In Section 4.1, we discuss our analyses of how increased reporting frequency affected the relative investment stock price sensitivity of treatment firms in the post-treatment period. In Section 4.2, we analyze dynamic timing effects of increased reporting frequency to investigate the parallel trends assumption necessary for a difference-in-differences analysis.

\subsection{Increased reporting frequency and Investment Price Sensitivity}

The results for estimating Equation (1) are presented in Table 4 where $C H G_{-} P P E$ and CAPEX are the respective measures of investment. The full sample results are presented in Columns 1 and 2 while the mandatory sample results are shown in Columns 3 and 4 . Since the two sets of results are similar, we focus our discussion on the full sample results. The results in Columns 1 and 2 show the coefficients on $Q$ are positive and highly significant $(p$-values $<0.01)$. Thus, consistent with prior literature (Chen et al. 2007; Edmans et al. 2017), $Q$ is positively associated with the level of investment, measured either by the one-year-ahead change in property, plant, and equipment or the one-year-ahead capital expenditure for non-treatment firms during the pre-treatment period. In addition, the $P O S T \times Q$ coefficients are small in absolute magnitude and not significantly different from zero. Thus, on average, the control firms did not experience a significant change in IPS during the post-treatment period.

The coefficient on TREAT $\times Q$ captures the difference in IPS for treatment firms relative to control firms during the pre-treatment period. In both Columns 1 and 2 , the $T R E A T \times Q$ coefficient is negative and significant ( $p$-values $<0.05)$. Thus, the IPS of treatment firms is significantly less 
than that of control firms during the pre-treatment period. While we cannot causally attribute lower sensitivity of investments to stock prices during the pre-treatment period to their lower reporting frequency, this difference is consistent with our hypothesized effect of reporting frequency on IPS.

Our main variable of interest is the interaction term $T R E A T \times P O S T \times Q$, which captures the incremental change in IPS in the post-treatment period for treatment firms relative to the change experienced by controls firms. In both Columns 1 and 2 , the $T R E A T \times P O S T \times Q$ coefficient is positive and significant at the $1 \%$ level. These results indicate that relative to the (insignificant) change experienced by controls firms, IPS increased significantly in the post-treatment period for treatment firms. The results for the mandatory sample in Columns 3 and 4 are similar. Both $T R E A T \times P O S T \times Q$ coefficients are significantly positive $(p$-values $<0.05)$ and their magnitudes are similar to but slightly smaller than their counterparts in Columns 1 and 2. Collectively, these findings indicate the increase in reporting frequency caused managers' investment decisions to be more highly associated with stock prices. ${ }^{16}$ As such, they provide empirical support for our hypothesis that managers learn more new investment-related information from stock prices following an increase in reporting frequency. In addition, our results are consistent with the theoretical prediction in Goldstein and Yang (2019).

To help in interpreting our regression results, we visual depict the Table 4 results in Figures 2 and 3, which are based on the full and mandatory samples, respectively. In Panel A of each figure, we present the IPS results for when the change in PP\&A is the dependent variable for the treatment and control firms in both the pre-treatment and post-treatment periods. The equivalent IPS results when capital expenditures is the dependent variable are presented in Panel B.

\footnotetext{
${ }^{16}$ The change in reporting frequency for the mandatory sample is based on exogenous regulatory shocks. In contrast, the decision to change reporting frequency for the voluntary switchers could be correlated with changes in IPS. Thus, our ability to more precisely identify the likely causal effects of the change in reporting frequency is higher for the mandatory sample. Since the results for both samples are similar, self-selection issues are less likely to be an issue.
} 
The results across the two samples and the two investment measures are remarkably similar. During the pre-treatment period, the magnitudes of the mean IPS for the treatment firms are about one-fourth to one-third the magnitude of IPS for the control firms. Comparing the pre- and posttreatment periods for the control firms shows that there is almost no difference in the mean value of IPS. Thus, there is no evidence of a structural break or trend in IPS for firms that do not change their reporting frequency. In stark contrast, the mean IPSs for the treatment firms are dramatically higher in the post-treatment period. The average increase is so large that in each panel, the mean value of IPS for treatment firms is larger than the corresponding values for control firms (although the differences are relatively small).

As discussed above, the results show IPS was significantly lower for treatment firms than control firms during the pre-treatment period but increased significantly more for treatment firms compared to control firms in the post-treatment period. We attribute these differences to the effects of differences in reporting frequency on the investment-related information in stock prices as opposed to other differences between treatment and control firms. If our interpretation is correct, then one implication is that conditional on the control variables, IPS should be similar for treatment and control firms during the post-treatment period. During the post-treatment period, IPS for control firms is captured by the sum of the $Q$ and $P O S T \times Q$ coefficients while IPS for treatment firms is captured by the sum of the $Q, P O S T \times Q, T R E A T \times P O S T$, and TREAT $\times P O S T \times Q$ coefficients. The results of untabulated F-tests indicates that the two sums are not significantly different from each other regardless of which measure of investment is used. These findings increase our ability to attribute the differences in IPS to the effects of reporting frequency.

In addition to their statistical significance, the economic magnitude of the effects is large. This can be clearly seen in Figures 2 and 3. As discussed above, the average values of ISP for the 
treatment firms go from substantially smaller than for the control firms to being larger during the post-treatment period. For example, when the change in PPE is the measure of investment, the magnitude of IPS for treatment firms during the pre-treatment period for the full sample is 0.005 $(=0.0156+-0.0111)$. The pre-treatment magnitude is only $32 \%$ of the magnitude for the control firms during the pre-treatment period (0.0156). However, during the post-treatment period, the magnitude for the treatment firms is $0.019(=0.005+-0.00033+0.0145)$. This value is $24 \%$ greater than the value for the control firms $(0.0153=0.0156+-0.000331)$. In addition, the increase in IPS roughly corresponds to $15.9 \%$ of the standard deviation of change in property, plant, and equipment for the full sample, which further indicates an economically meaningful increase in the stock price informativeness to mangers. In summary, treatment firms substantially increased their reliance on stock price when making investment decisions during the post-treatment period.

Lastly, it is worth discussing the results for $P O S T$ and $T R E A T \times P O S T$. These results capture changes in the level of investment, as opposed to changes in IPS. The POST coefficients are negative and marginally significant (insignificant) in Columns 1 and 3 ( 2 and 4 ). Thus, they suggest a marginal decrease (at most) in the level of investment for control firms during the post-treatment period. The TREAT $\times P O S T$ coefficients are all negative and significant ( $p$-values $<0.05,0.10,0.05$, and 0.05 , respectively). These results indicate that during the post-treatment period, treatment firms reduced their levels of investment relative to that of control firms. These results are consistent with those in Kraft et al. (2018), who also find the decrease is concentrated among treatment firms with longer investment cycles. They attribute their results to an increase in managerial myopia. We note that the investment level and IPS results are not inconsistent with each other as even myopic managers will use all available information, including that in stock prices, to make the best investment decisions given their horizon preferences. 


\subsection{Dynamic timing effect of reporting frequency increases on Investment Price Sensitivity}

An important assumption of the difference-in-differences research design is that prior to reporting frequency increases, treatment firms and control firms have similar trends in IPS (i.e., the parallel trends assumption). To provide evidence on the validity of this assumption and to better understand the dynamics of IPS over time, we modify Equation (1) and include POST(-1), POST $(+1,+2)$, and POST $(+3,+5)$ and their interactions with $Q$ and TREAT. POST $(-1)$ is an indicator variable equal to one if the observation period is one year preceding the beginning of the treatment period, and zero otherwise. $\operatorname{POST}(+1,+2)\{\operatorname{POST}(+3,+5)\}$ in an indicator variable equal to one if the observation period falls between one year and two years \{three years and five years\} after the beginning of the treatment period, and zero otherwise.

The results from using the full sample (mandatory sample) are reported in Columns 1 and 2 (3 and 4). They full sample results show that during the year preceding the treatment period, the magnitudes and changes in IPS are similar for treatment and control firms, as the coefficient on the interaction term TREAT $\times P O S T(-1) \times Q$ is not significant. In contrast, the coefficients on $T R E A T \times P O S T(+1,+2) \times Q$ and $T R E A T \times P O S T(+3,+5) \times Q$ are positive and statistically significant at the $1 \%$ level. Columns 3 and 4 indicate that results are similar when we use the mandatory sample, although the significance levels are slightly lower. The fact that the increase in IPS is persistent for at least five years indicates the increase in reporting frequency results in a permanent change in the information environment. Thus, the results of this alternative specification provide additional evidence supporting our hypothesis as well as mitigate concerns over the validity of our research design. 


\subsection{Increases in reporting frequency and the managerial learning channel}

The evidence discussed above indicates investment levels at treatment firms were more highly associated with stock prices after they began to report more frequently relative to control firms. This result implies that managers at treatment firms behaved as if they believed their stock prices contained relatively more investment-related informative that was new to them during the post-treatment period. In other words, our results are consistent with the managerial learning channel (Chen et al. 2007; Edmans et al. 2017).

Recall from Section 2 that the hypothesized managerial learning channel relies on the increase in financial reporting frequency leading to two changes in the information environment. First, there is an increase in private information incorporated into stock prices. Second, there must be an increase in the investment-related information in stock prices that is new to the manager. In this section, we conduct additional analyses to provide evidence on whether the changes in the information environment are consist with the managerial learning channel.

In the first set of tests, we examine whether the relative increase in IPS for treatment firms is larger when stocks are more heavily traded by privately informed investors. More trading by informed investors will increase the amount of private information reflected in stock prices. To the extent at least some of this information represents investment-relevant information that is new to managers, then we expect the increase in IPS will be more pronounced for firms with more informed trading.

Following Chen et al. (2007) and Jayaraman and $\mathrm{Wu}$ (2019), we proxy for the amount of private information in stock prices using stock price nonsynchronicity $\left(1-\mathrm{R}^{2}\right)$ and the Amihud's 
(2002) stock illiquidity measure. ${ }^{17}$ Stock price nonsynchronicity is a firm-specific measure equal to one minus the R-square from firm-specific regressions of firm level returns on market returns and industry returns (Durnev et al. 2003). Higher values correspond to more trading based on private information. Stock illiquidity is also a firm-specific measure estimated from the average of the ratio of daily unsigned stock returns scaled by dollar trading volume (multiplied by $10^{6}$ ) expressed in percentage points (Amihud 2002). Higher values correspond to more trading based on private information.

For each measure, we divide the sample into two subsamples as follows. In each year, we compute the median value of the measure (either $\left(1-\mathrm{R}^{2}\right)$ or Illiquidity). Then based on that year's median value, observations from that year are assigned to the high (low) group if the firm's measure is above (below) the median value. This process is done separately for the full sample and the mandatory sample. ${ }^{18}$ This process results in four subsamples for the full sample (High $\left(1-\mathrm{R}^{2}\right)$, Low $\left(1-\mathrm{R}^{2}\right)$, High Illiquidity, Low Illiquidity) and four subsamples for the mandatory sample. For each subsample, we estimate Equation (1). The results using the full sample are presented in Panel A of Table 6 while the results from the mandatory sample are in presented in Panel B. For the sake of brevity, we do not tabulate the results for the control variables. The results using the mandatory sample are similar to those from the full sample. Thus, we focus on the full sample results.

Column 1 presents the results for the High $\left(1-\mathrm{R}^{2}\right)$ sample where the year-ahead change in PP\&E is the dependent variable. The coefficient on the triple interaction variable of interest, $T R E A T \times P O S T \times Q$, is positive and significant $(p$-value $<0.01)$. In addition, the magnitude of the

\footnotetext{
${ }^{17}$ (Chen et al. 2007) also use the probability of informed trading (PIN) as an additional proxy. Constructing this measure requires intra-day data on trades and spreads (to sign the trades). This information is unavailable during our sample period, and hence, we are unable to use this measure.

${ }^{18}$ For the full sample, the set of the control firms is the same as before. For the mandatory sample, we follow (Kraft et al. 2018) and eliminate the small number of firms that reported three times in a year.
} 
coefficient, 0.0392, is over twice as large as its Table 4 counterpart, 0.0145 . In contrast, the $T R E A T \times P O S T \times Q$ coefficient in Column 2 for the Low $\left(1-\mathrm{R}^{2}\right)$ sample is small in magnitude (0.00253) and not significant. The results in Columns 3 and 4 where the year-ahead capital expenditures is the dependent variable are similar. Specifically, the $T R E A T \times P O S T \times Q$ coefficient is positive and highly significant in the High $\left(1-\mathrm{R}^{2}\right)$ sample but is insignificant in the Low $\left(1-\mathrm{R}^{2}\right)$ sample. The corresponding results in Panel B for the mandatory sample are qualitative similar with positive and significant coefficients in the High $\left(1-\mathrm{R}^{2}\right)$ sample but insignificant coefficients in the Low $\left(1-\mathrm{R}^{2}\right)$ sample.

The corresponding full sample results when Illiquidity is used to create the subsamples are presented in Columns $5-8$. The pattern of results is similar to that in Columns $1-4$. Specifically, the TREAT $\times P O S T \times Q$ coefficients are positive and significant $(p$-values $<0.05)$ for the High Illiquidity subsample but are small in magnitude and insignificant in the Low Illiquidity subsample.

In summary, when the stocks of treatment firms have relatively high levels of privately information trading, IPS is significantly higher following the increase in quarterly reporting relative to control firms. In contrast, treatment firms exhibit no significant increase in IPS following the increase in quarterly reporting relative to control firms when there is relatively little informed trading in their stocks. Overall, the results in Table 6 are consistent with our expectations. When stocks are expected to contain relatively high amounts of private information, managers appear to place more weight on this information when making their investment decisions, and vice-versa.

According to the managerial learning channel, managers increase their reliance on stock prices when making investment decisions when they think stock prices contain information that is superior to their own. If descriptive, then our prior results indicate that managers will have made 
relatively better (or more informed) investment decisions during the post-treatment period given the improvement in their information sets. In which case, we expect the future operating performance of treatment firms' will improve relative to control firms as they make more informed investment decisions.

In our second set of tests, we provide evidence on this implication of the managerial learning channel by examining whether increases in reporting frequency are positively associated with future return on assets (ROA). Specifically, we estimate versions of Equation (1) where either 1. ROA in the following year (ROA $[+1]), 2$. the average annual ROA over the next two years (ROA $[+1,+2]$, and 3. the average annual ROA over the next three years (ROA $[+1,+3]$. The results for the full sample are presented in Columns $1-3$ of Table 7 , and the mandatory sample results are presented in Columns $4-6$.

The main coefficient of interest is the TREAT $\times P O S T$ interaction variable. Its coefficient captures the incremental change in future ROA for treatment firms in the post-treatment period relative to the concurrent change experienced by the control firms. In each of Columns $1-3$, the $T R E A T \times P O S T$ coefficient is positive and significant $(p$-values $<0.10$ ). For the mandatory sample, the results in Columns 5 and 6 also show the TREAT $\times P O S T$ coefficients are positive and significant ( $p$-values $<0.05$ and 0.10 , respectively). However, when average ROA over the next three years is the dependent variable, the TREAT $\times P O S T$ coefficient is insignificant. Overall, the future profitability results in Table 7 are consistent with managers making relatively better investment decisions during the post-treatment period, when their investment decisions are also more highly associated with stock prices. Thus, the results in Table 7 provide additional corroborating evidence that our main IPS results are due to the managerial learning channel. 


\subsection{Financial Constraints Channel}

In this section, we examine an alternative explanation for our results based on the financial constraints channel (Baker et al. 2003). They argue that when firms are financially constrained, they need to rely more on equity issuances to fund their investments. Given the costs and frictions associated with issuing equity, constrained firms are unable to finance their optimal investment plans. In which case, increases (decreases) in equity prices will relax (tighten) these constraints, and equity-dependent firms will respond by increasing (decreasing) their level of investment accordingly. Thus, investments are positively correlated with stock prices (i.e., IPS is positive) but this correlation does not imply managers are learning about the profitability of their investment opportunities from stock prices. Consistent with this reasoning, Baker et al. (2003) predict and find IPS is increasing in the level of financial constraints.

In order to provide evidence on the validity of this alternative explanation, we examine whether the relative increase in IPS for treatment firms during the post-treatment period is higher for more financing constrained treatment firms. Similar to the procedures used in Table 6, we divide the sample into more and less equity dependent subsamples using three different measures of financing constraints used in prior literature. The first two measures are firm age (AGE) and firm size (SIZE). Hadlock and Pierce (2010) find that these two variables are the most reliable measures of financing constraints that they examine, where younger firms and smaller firms face higher financing constraints. We also use the KZ index developed in Baker et al. (2003), which is also used in Chen et al. (2007).

For each measure, we split the sample based on the cross-sectional median annual value of the constraints measure. We designate the group of firms with above median values of financing constraints as HIGH FC, and the group of firms with below median values of financing constraints 
as Low FC. We then modify Equation (1) and allow our interaction variable of interest, $T R E A T \times P O S T \times Q$, to take on different values for the HIGH FC and LOW FC groups. The results for the full sample (mandatory sample) are reported in Panel A (Panel B) of Table 8.

The full sample results show that for each measure of financing constraints and each measure of investment, the $T R E A T \times P O S T \times Q$ coefficient is positive and significant for the LOW FC group (five of six $p$-values $<0.01$ ). In contrast, none of the $T R E A T \times P O S T \times Q$ coefficients are significant for the HIGH FC group. ${ }^{19}$ The results in Panel B for the mandatory sample are qualitatively the same: all of the $T R E A T \times P O S T \times Q$ coefficients are significant for the LOW FC group at the $5 \%$ level or better while none of the $T R E A T \times P O S T \times Q$ coefficients are significant for the HIGH FC group. In summary, the evidence does not support the alternative explanation that our results are being driven by the financial constraints channel. Instead, the evidence is most consistent with the learning channel. In addition, the evidence is also consistent with the intuition in Chen et al. (2007) that the managers of the less financially constrained firms can respond to information in their firm's stock price more easily in adjusting their investments.

\section{Summary and Conclusion}

Mandatory reporting frequency is an important but difficult regulatory design choice because it fundamentally affects the information environment for publicly traded firms. The difficulty in determining the optimal reporting frequency occurs because reporting frequency affects the incentives of numerous market participants, including analysts, investors, creditors, competitors, as well as managers, in diverse and often imperfectly understood ways. Not surprisingly, financial reporting frequency has been a controversial issue subject to much policy

\footnotetext{
${ }^{19}$ These results are inconsistent with those in Baker et al. (2003), who rely on the KZ measure of financing constraints (Kaplan and Zingales 1997). As shown in Hadlock and Pierce (2010), the KZ measure is an unreliable measure of financing constraints. Therefore, the differences between our results and those in Baker et al. (2003) maybe due measurement errors in the $\mathrm{KZ}$ measure.
} 
debate globally. In this paper, we provide evidence relevant to this debate by examining how financial reporting affects the degree to which managers rely on information in stock prices to make their investment decisions in a setting that allows for causal inferences.

We examine changes in U.S. firms' financial reporting frequency over the period 19511974. During this period, the SEC first increased the mandatory reporting frequency from annual to semi-annual in 1955 and then from semi-annual to quarterly in 1970. We use investment-toprice sensitivity (hereafter, IPS) to measure the degree to which managers learn new information about the value of their investment opportunities from stock prices (Bakke and Whited 2010; Chen et al. 2007; Edmans et al. 2017; Foucault and Fresard 2012; Jayaraman and Wu 2019).

Our primary results indicate IPS significantly increased for treatment firms following the increase in reporting frequency compared to control firms. We find the increase in reporting frequency resulted in long-lasting increases in IPS as the effects are significant for at least five years following the increase in reporting frequency. The results are economically significant as well. Thus, consistent with our hypothesis, the evidence indicates managers of treatment firms behaved as if their stock prices contained more information about investment opportunities when they made their investment decisions during the post-adoption period.

The results from additional tests provide corroborating evidence that our results are driven by the managerial learning channel, as we hypothesize. Specifically, we find the relative increase in investment-stock price sensitivity is concentrated among firms whose stocks have relatively high levels of informed trading. This finding is consistent with informed investors impounding investment-related information in stock prices through their trading activities. In addition, we find evidence that following the increase in reporting frequency, managers at treatment firms make 
relatively more investment decisions. Thus, our results indicate a real effect of reporting frequency on the quality of firms' investment decisions. 


\section{References}

Alford, A., J. Jones, R. Leftwich, and M. Zmijewski. 1993. "The Relative Informativeness of Accounting Disclosures in Different Countries." Journal of Accounting Research 31: 183, https://doi.org/10.2307/2491170.

Amihud, Y. 2002. "Illiquidity and stock returns: cross-section and time-series effects." Journal of financial markets 5 (1): 31-56.

Badertscher, B., N. Shroff, and H. D. White. 2013. "Externalities of public firm presence: Evidence from private firms' investment decisions." Journal of Financial Economics 109 (3): 682706, https://doi.org/10.1016/j.jfineco.2013.03.012.

Baker, M., J. C. Stein, and J. Wurgler. 2003. "When Does the Market Matter? Stock Prices and the Investment of Equity Dependent Firms." Quarterly Journal of Economics 118(3): 9691005.

Bakke, T.-E., and T. M. Whited. 2010. "Which firms follow the market? An analysis of corporate investment decisions." Review of Financial Studies 25(3): 1941-80.

Bhushan, R. 1989a. "Collection of information about publicly traded firms: theory and evidence." Journal of Accounting and Economics 11: 183-206.

Bhushan, R. 1989b. "Firm Characteristics and Analyst Following." Journal of Accounting and Economics 11 (2,3): 255-74.

Bond, P., A. Edmans, and I. Goldstein. 2012. "The Real Effects of Financial Markets." Annual Review of Financial Economics 4 (1): 339-60, https://doi.org/10.1146/annurev-financial110311-101826.

Brown, S., and S. Hillegeist. 2007. "How Disclosure Quality Affects the Level of Information Asymmetry." Review of Accounting Studies 12: 443-77.

Butler, M., A. Kraft, and I. S. Weiss. 2007. "The effect of reporting frequency on the timeliness of earnings: The cases of voluntary and mandatory interim reports." Journal of Accounting and Economics 43 (2-3): 181-217, https://doi.org/10.1016/j.jacceco.2007.02.001.

Chen, Q., I. Goldstein, and W. Jiang. 2007. "Price informativeness and investment sensitivity to stock price.” Review of Financial Studies 20(3): 619-50.

Demski, J. S., and G. A. Feltham. 1994. "Market response to financial reports." Journal of Accounting and Economics 17 (1,2): 3-40.

Dow, J., and G. Gorton. 1997. "Stock Market Efficiency and Economic Efficiency: Is There a Connection?" The Journal of Finance 52 (3): 1087-1129, https://doi.org/10.1111/j.15406261.1997.tb02726.x. 
Durnev, A., R. Morck, B. Yeung, and P. Zarowin. 2003. "Does greater firm-specific return variation mean more or less informed stock pricing?" Journal of Accounting Research 41 (5): 797-836.

Edmans, A., I. Goldstein, and W. Jiang. 2015. "Feedback Effects, Asymmetric Trading, and the Limits to Arbitrage." American Economic Review 105 (12): 3766-97.

Edmans, A., S. Jayaraman, and J. Schneemeier. 2017. "The source of information in prices and investment-price sensitivity." Journal of Financial Economics 126 (1): 74-96, https://doi.org/10.1016/j.jfineco.2017.06.017.

Einhorn, E. 2005. "The Nature of the Interaction between Mandatory and Voluntary Disclosures." Journal of Accounting Research 43 (4): 593-621, https://doi.org/10.1111/j.1475679X.2005.00183.x.

Ernstberger, J., B. Link, M. Stich, and O. Vogler. 2017. "The Real Effects of Mandatory Quarterly Reporting.” The Accounting Review 92 (5): 33-60, https://doi.org/10.2308/accr-51705.

Foucault, T., and L. Fresard. 2012. "Cross-listing, investment sensitivity to stock price and the learning hypothesis." Review of Financial Studies 25(11): 3305-50.

Foucault, T., and L. Fresard. 2014. "Learning from peers' stock prices and corporate investment." Journal of Financial Economics 111(3): 554-57.

Fu, R., A. G. Kraft, X. Tian, H. Zhang, and L. Zuo. 2019. "Financial Reporting Frequency and Corporate Innovation." City University London working paper.

Fu, R., A. Kraft, and H. Zhang. 2012. "Financial reporting frequency, information asymmetry, and the cost of equity." Journal of Accounting and Economics 54 (2-3): 132-49, https://doi.org/10.1016/j.jacceco.2012.07.003.

Gigler, F., and T. Hemmer. 1998. "On the Frequency, Quality, and Informational Role of Mandatory Financial Reports.” Journal of Accounting Research 36 (Supplement): $117-47$.

Gigler, F., and T. Hemmer. 2001. "Conservatism, Optimal Disclosure Policy, and the Timeliness of Financial Reports." The Accounting Review 76 (4): 471-93, https://doi.org/10.2308/accr.2001.76.4.471.

Goldstein, I., and L. Yang. 2015. "Information Diversity and Complementarities in Trading and Information Acquisition: Complementarities in Trading and Information Acquisition." The Journal of Finance 70 (4): 1723-65, https://doi.org/10.1111/jofi.12226.

Goldstein, I., and L. Yang. 2019. "Good disclosure, bad disclosure." Journal of Financial Economics 131 (1): 118-38, https://doi.org/10.1016/j.jfineco.2018.08.004. 
Gormley, T. A., and D. A. Matsa. 2014. "Common Errors: How to (and Not to) Control for Unobserved Heterogeneity." Review of Financial Studies 27 (2): 617-61, https://doi.org/10.1093/rfs/hht047.

Grossman, S., and J. Stiglitz. 1980. "On the Impossibility of Informationally Efficient Markets." American Economic Review 70 (3): 393-408.

Hadlock, C. J., and J. R. Pierce. 2010. "New Evidence on Measuring Financial Constraints: Moving Beyond the KZ Index." Review of Financial Studies 23 (5): 1909-40, https://doi.org/10.1093/rfs/hhq009.

Healy, P., A. Hutton, and K. Palepu. 1999. "Stock Performance and Intermediation Changes Surrounding Sustained Increases in Disclosures." Contemporary Accounting Research 16 (3): 485-520.

Healy, P., and K. Palepu. 2001. "Information asymmetry, corporate disclosure, and the capital markets: A review of the empirical disclosure literature." Journal of Accounting \& Economics 31 (1-3): 405-40.

Hutton, A. P., L. F. Lee, and S. Z. Shu. 2012. "Do Managers Always Know Better? The Relative Accuracy of Management and Analyst Forecasts." Journal of Accounting Research 50 (5): 1217-44, https://doi.org/10.1111/j.1475-679X.2012.00461.x.

Jayaraman, S., and J. S. Wu. 2019. "Is Silence Golden? Real Effects of Mandatory Disclosure." Review of Financial Studies 32(6): 2225-59.

Kaplan, S. N., and L. Zingales. 1997. "Do Investment-Cash Flow Sensitivities Provide Useful Measures of Financing Constraints?" The Quarterly Journal of Economics 112 (1): 169215, https://doi.org/10.1162/003355397555163.

Kim, O., and R. E. Verrecchia. 1991. "Market Reaction to Anticipated Announcements." Journal of Financial Economics 30 (2): 273-309.

Kothari, S. P., K. Ramanna, and D. J. Skinner. 2010. "Implications for GAAP from an analysis of positive research in accounting." Journal of Accounting and Economics 50 (2-3): 246-86, https://doi.org/10.1016/j.jacceco.2010.09.003.

Kraft, A. G., R. Vashishtha, and M. Venkatachalam. 2018. "Frequent Financial Reporting and Managerial Myopia." The Accounting Review 93 (2): 249-75, https://doi.org/10.2308/accr51838.

Lang, M., and R. Lundholm. 1993. "Cross-sectional Determinants of Analyst Ratings of Corporate Disclosures.” Journal of Accounting Research 31 (2): 246-71.

McNichols, M., and J. G. Manegold. 1983. "The Effect of the Information Environment on the Relationship Between Financial Disclosure and Security Price Variability." Journal of Accounting \& Economics 5 (1): 49-74 49. 
McNichols, M., and B. Trueman. 1994. "Public disclosure, private information collection, and short-term trading." Journal of Accounting and Economics 17 (1,2): 69-94.

Shin, H.-H., and R. M. Stulz. 1998. “Are Internal capital Markets Efficient?" The Quarterly Journal of Economics 113 (2): 531-52, https://doi.org/10.1162/003355398555676.

Taylor, R. 1963. “Examination of Published Interim Reports.” University of Chicago.

Verrecchia, R. E. 2001. "Essays on disclosure.” Journal of Accounting \& Economics 32 (1-3): 97-180.

Welker, M. 1995. "Disclosure policy, information asymmetry, and liquidity in equity markets." Contemporary Accounting Research 11 (2): 801-27.

Whited, T. M. 2006. "External finance constraints and the intertemporal pattern of intermittent investment." Journal of Financial Economics $81 \quad$ (3): 467-502, https://doi.org/10.1016/j.jfineco.2005.07.007. 


\section{Appendix: Variable Definitions}

\begin{tabular}{|c|c|}
\hline Variable & Definition \\
\hline CHG_PPEt+1 & $\begin{array}{l}\text { One period ahead change in net property plant and equipment } \\
\left(\text { PPENT }_{t+1}-\text { PPENT) divided by total assets (AT) }\right.\end{array}$ \\
\hline CAPEX $\mathrm{t}_{+1}$ & $\begin{array}{l}\text { One period ahead capital expenditure }\left(\mathrm{CAPX} \mathrm{X}_{\mathrm{t}+1}\right) \text { divided by total } \\
\text { assets (AT) }\end{array}$ \\
\hline Q & $\begin{array}{l}\text { Tobin's Q calculated as market value of assets divided by book value } \\
\text { of assets. }\end{array}$ \\
\hline AT & Total Assets in \$millions \\
\hline SIZE & The natural logarithm of total assets \\
\hline $\mathrm{CF}$ & $\begin{array}{l}\text { Income before extraordinary items plus depreciation (IB + DP) } \\
\text { divided by total assets (AT) }\end{array}$ \\
\hline LEVERAGE & Long-term debt (DLTT) divided by total assets (AT) \\
\hline SALESGROWTH & Percentage change in sales (SALE) \\
\hline LIQUIDITY & Current assets (ACT) divided by current liabilities (LCT) \\
\hline KZ Index & $\begin{array}{l}\text { Four-variable KZ score (excluding Q) per Kaplan and Zingales } \\
(1997) \text {, measured by a weighted sum of cash flow }\left(\mathrm{CF}_{t}\right) \text {, cash } \\
\text { dividends }(\mathrm{DIV}) \text {, and cash balances }\left(\mathrm{C}_{\mathrm{t}}\right) \text {, all scaled by beginning-of- } \\
\text { year assets }\left(\mathrm{A}_{\mathrm{t}-1}\right) \text {, as well as leverage ratio }(\mathrm{LEV}): \mathrm{KZ} 4= \\
-1.002 \times \mathrm{CF}_{\mathrm{it}} / \mathrm{A}_{\mathrm{it}-1}-39.368 \times \mathrm{DIV} \mathrm{V}_{\mathrm{it}} / \mathrm{A}_{\mathrm{it}-1}-1.315 \times \mathrm{C}_{\mathrm{it}} / \mathrm{A}_{\mathrm{it}-1}+3.139 \times \mathrm{LEV}_{\mathrm{it}}\end{array}$ \\
\hline $1-\mathrm{R}^{2}$ & $\begin{array}{l}\text { One minus the R-square from regressions of firm level returns on } \\
\text { market returns and industry returns as per Durnev et al. (2003) }\end{array}$ \\
\hline ILLIQ & $\begin{array}{l}\text { The average of the ratio of daily unsigned stock returns scaled by } \\
\text { dollar trading volume multiplied by } 10^{6} \text {, expressed in percentage } \\
\text { points, following Amihud (2002) }\end{array}$ \\
\hline TREAT & $\begin{array}{l}\text { A dummy variable which equals } 1 \text { for firms that increase their } \\
\text { reporting frequency, and } 0 \text { otherwise. }\end{array}$ \\
\hline POST & $\begin{array}{l}\text { A dummy variable which equals } 1 \text { for firms-year observations after } \\
\text { the treatment year, and } 0 \text { otherwise. }\end{array}$ \\
\hline ROA & Income before extraordinary items (IB) divided by total assets (AT) \\
\hline
\end{tabular}


Figure 1. Timeline of key dates in the SEC's regulation of financial reporting frequency.

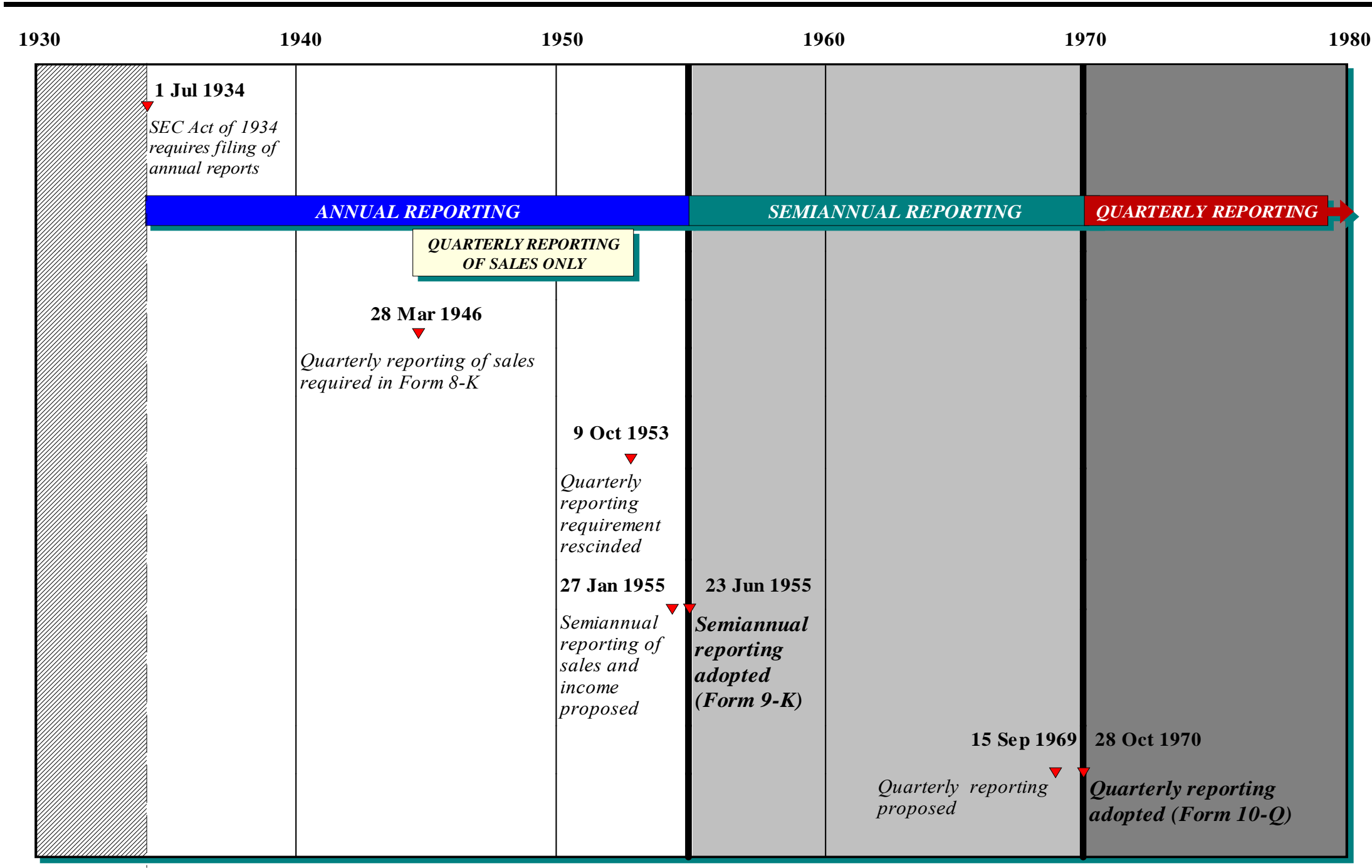


Figure 2 - Full Sample

Panel A: Investment measured by the change in Property, Plant, \& Equipment

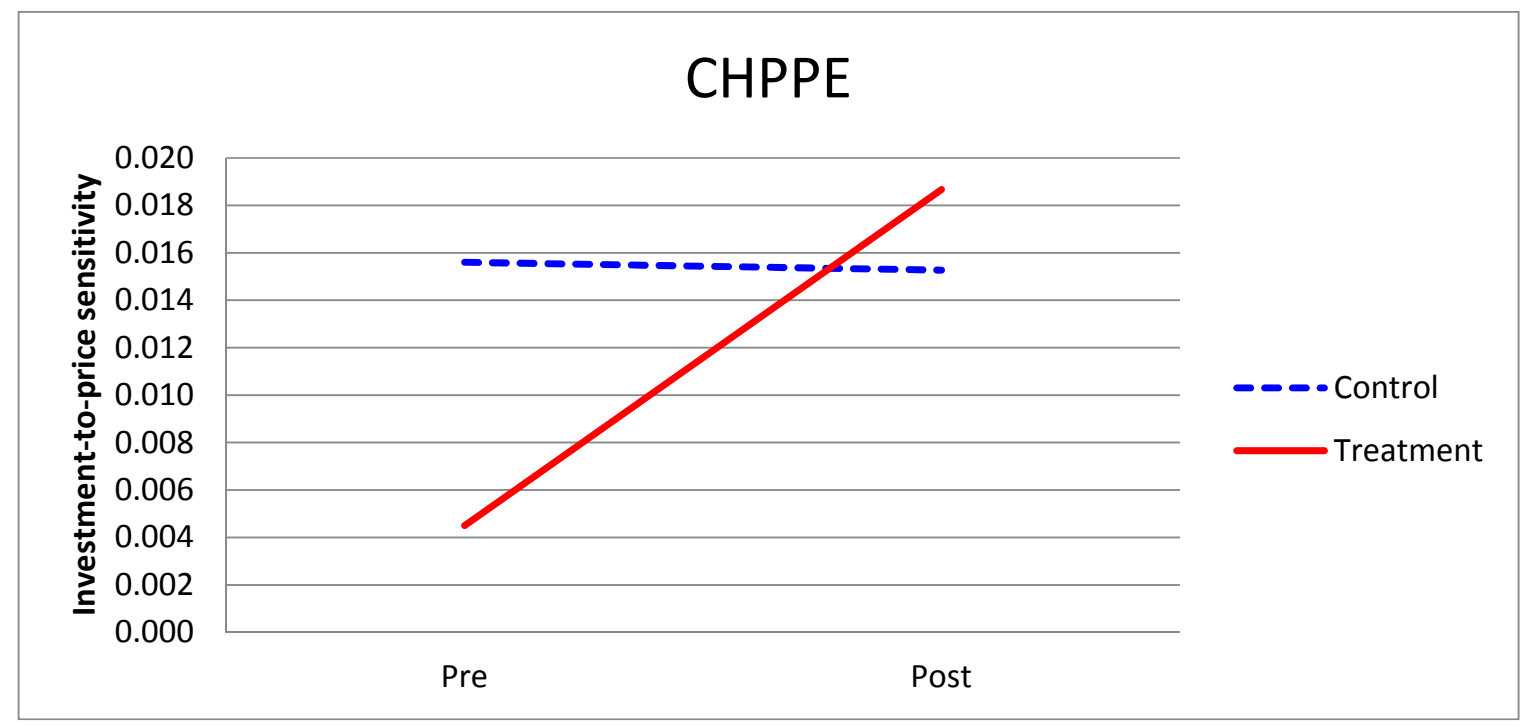

Panel B: Investment measured by the Capital Expenditures

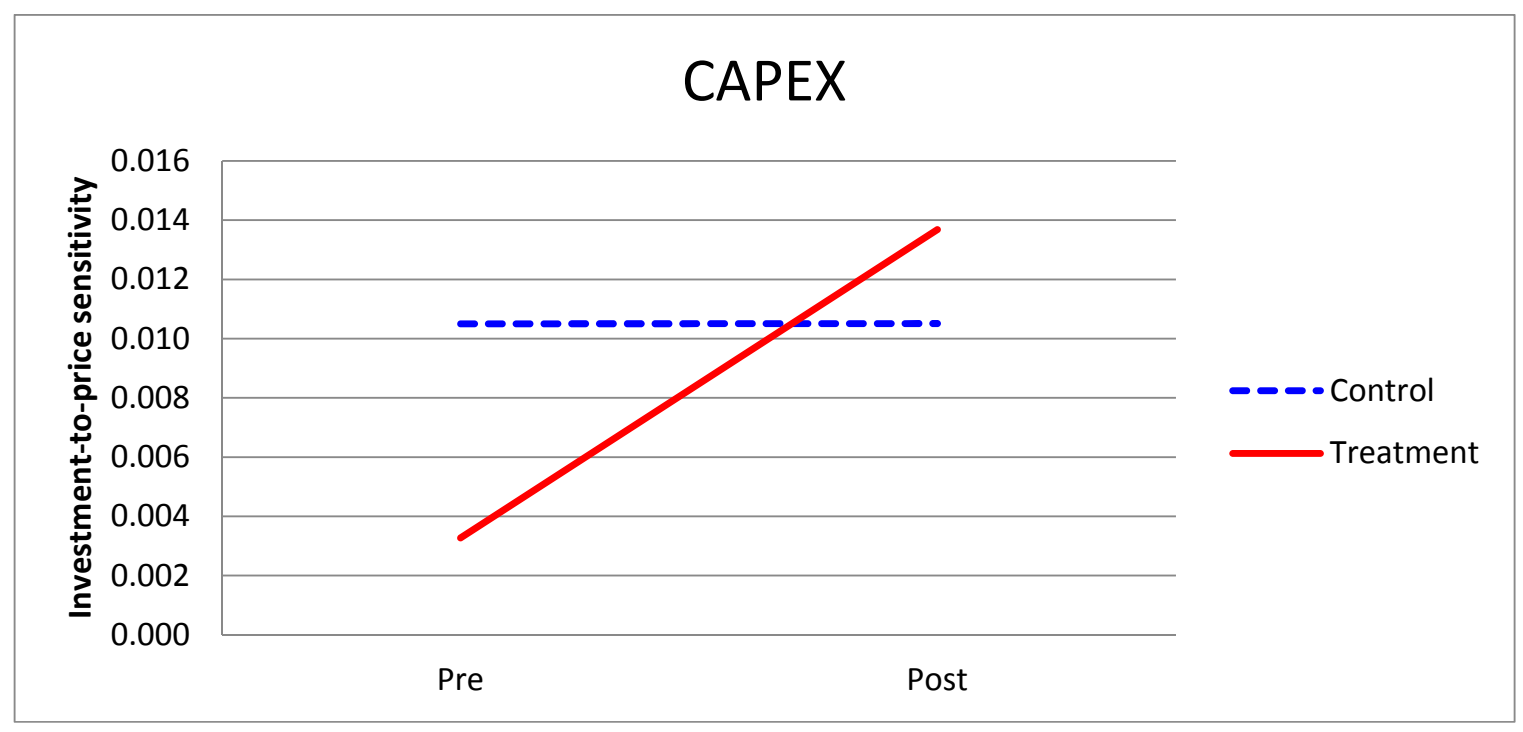

Figure 2 is based on the full sample results from Table 4, Panel A, estimated using Equation (1). Figure 2 shows the trend in investment-price sensitivity for treatment and control firms before and after reporting frequency increases for control firms, and after controlling for changes in the control variables and fixed effects. 
Figure 3 - Mandatory Sample

\section{Panel A: Investment measured by the change in Property, Plant, \& Equipment}

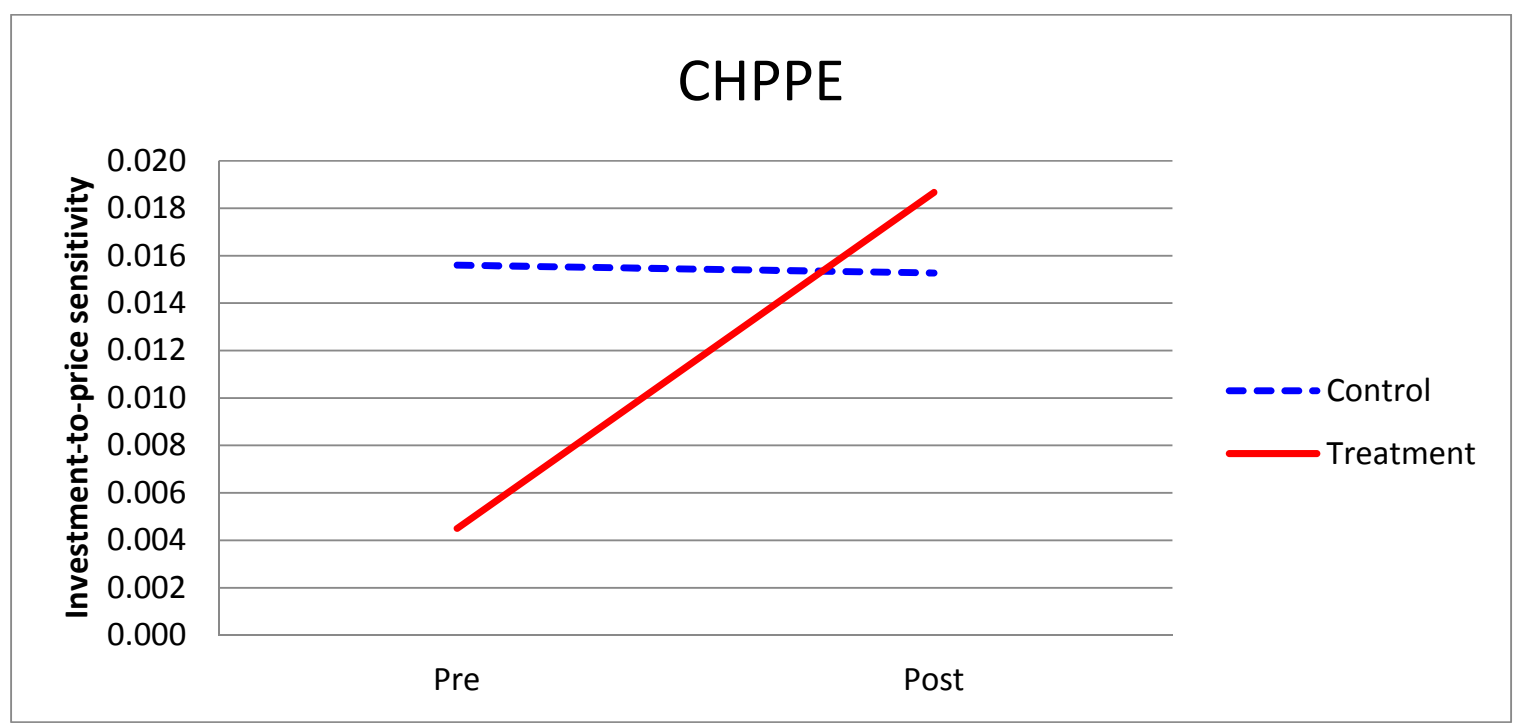

\section{Panel B: Investment measured by the Capital Expenditures}

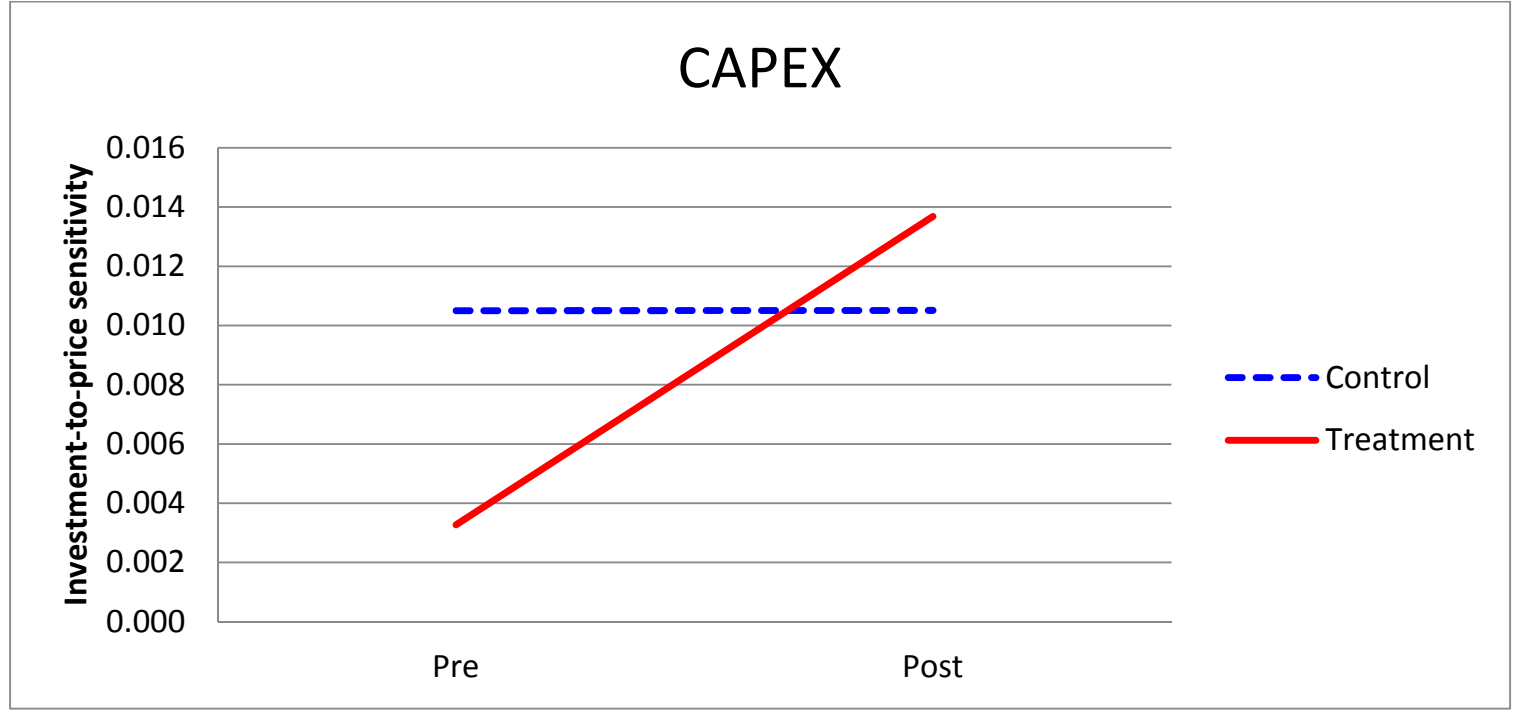

Figure 3 is based on the mandatory sample results from Table 4, Panel B, estimated using Equation (1). Figure 3 shows the trend in investment-price sensitivity for treatment and control firms before and after reporting frequency increases for control firms, and after controlling for changes in the control variables and fixed effects. 
Table 1 - Sample distribution and matching statistics

Panel A: Distribution of treatment firms

Increases in reporting

frequency to

Full sample $\quad$ Mandatory sample

Twice a year (semi-annual)

149

128

Three time a year

141

0

Four time a year (quarterly)

596

364

Total

886

492

Panel B: Comparison of matching variables

\begin{tabular}{lcccccr}
\hline & \multicolumn{3}{c}{ Full sample } & \multicolumn{3}{c}{ Mandatory sample } \\
Variable & $\begin{array}{c}\text { Treatment } \\
\text { firm } \\
\text { means }\end{array}$ & $\begin{array}{c}\text { Control } \\
\text { firm } \\
\text { means }\end{array}$ & $\begin{array}{c}\text { Mean } \\
\text { difference } \\
\text { t-value }\end{array}$ & $\begin{array}{c}\text { Treatment } \\
\text { firm } \\
\text { means }\end{array}$ & $\begin{array}{c}\text { Control } \\
\text { firm } \\
\text { means }\end{array}$ & $\begin{array}{c}\text { Mean } \\
\text { difference } \\
\text { t-value }\end{array}$ \\
\hline SIZE & 3.231 & 3.261 & -0.493 & 3.071 & 3.123 & -0.645 \\
ROA & 0.062 & 0.063 & -0.406 & 0.064 & 0.065 & -0.216 \\
SALESGROWTH & 0.202 & 0.202 & -0.028 & 0.198 & 0.194 & 0.180 \\
LEVERAGE & 0.142 & 0.141 & 0.169 & 0.137 & 0.135 & 0.285 \\
& & & & & & \\
$\mathrm{~N}$ & 886 & 886 & & 492 & 492 & \\
\hline
\end{tabular}

Notes: Panel A provides the frequency distribution of treatment firms with reporting frequency increase across years 1951-1974 both for the full sample (include firms with voluntary and involuntary increases in reporting frequency) and the mandatory sample (involuntary increases in reporting frequency). Panel B presents the means of firm characteristics used for matching for treatment firm and control firms along with the t-values of differences in the mean values for both the full sample and mandatory sample. 
Table 2 - Descriptive statistics

Panel A: Full sample

\begin{tabular}{lcccccccc}
\hline Variable & Mean & SD & P1 & P25 & P50 & P75 & P99 & N \\
\hline CHG_PPE $_{t+1}$ & 0.045 & 0.091 & -0.111 & 0.000 & 0.022 & 0.062 & 0.497 & 11,364 \\
CAPEX $_{t+1}$ & 0.083 & 0.078 & 0.003 & 0.034 & 0.061 & 0.104 & 0.439 & 11,364 \\
Q & 1.881 & 1.393 & 0.579 & 1.164 & 1.561 & 2.173 & 6.702 & 11,364 \\
TOTAL ASSETS (\$'million) & 97 & 237 & 2 & 13 & 30 & 77 & 1253 & 11,364 \\
SIZE & 3.579 & 1.295 & 1.224 & 2.644 & 3.431 & 4.362 & 7.134 & 11,364 \\
CF & 0.098 & 0.057 & -0.060 & 0.068 & 0.098 & 0.128 & 0.237 & 11,364 \\
LEVERAGE & 0.145 & 0.129 & 0.000 & 0.029 & 0.129 & 0.225 & 0.547 & 11,364 \\
SALESGROWTH & 0.160 & 0.327 & -0.380 & 0.020 & 0.102 & 0.216 & 1.969 & 11,364 \\
LIQUIDITY & 2.784 & 1.378 & 0.729 & 1.873 & 2.480 & 3.334 & 8.846 & 11,364 \\
\hline
\end{tabular}

Panel B: Mandatory sample

\begin{tabular}{lcccccccc}
\hline Variable & Mean & SD & P1 & P25 & P50 & P75 & P99 & N \\
\hline CHG_PPE $_{t+1}$ & 0.046 & 0.091 & -0.119 & -0.001 & 0.022 & 0.063 & 0.496 & 6,180 \\
CAPEX $_{\mathrm{t}+1}$ & 0.083 & 0.079 & 0.003 & 0.034 & 0.061 & 0.106 & 0.472 & 6,180 \\
Q & 1.807 & 1.467 & 0.556 & 1.069 & 1.484 & 2.091 & 6.434 & 6,180 \\
TOTAL ASSETS (\$'million) & 91 & 262 & 2 & 11 & 25 & 60 & 1378 & 6,180 \\
SIZE & 3.396 & 1.296 & 1.189 & 2.453 & 3.239 & 4.116 & 7.229 & 6,180 \\
CF & 0.097 & 0.059 & -0.071 & 0.064 & 0.096 & 0.129 & 0.245 & 6,180 \\
LEVERAGE & 0.149 & 0.134 & 0.000 & 0.028 & 0.129 & 0.232 & 0.549 & 6,180 \\
SALESGROWTH & 0.163 & 0.316 & -0.367 & 0.020 & 0.107 & 0.224 & 1.645 & 6,180 \\
LIQUIDITY & 2.733 & 1.385 & 0.707 & 1.818 & 2.423 & 3.285 & 8.974 & 6,180 \\
\hline
\end{tabular}

Notes: Table 2 presents the descriptive statistics of the main variables for the treatment and control firms for both the full sample (Panel A) and the mandatory sample (Panel B). For both samples, we consider data for up to five years before and five years after the treatment year. Please refer to the Appendix for variable definitions. 


\section{Table 3 - Correlations}

\begin{tabular}{|c|c|c|c|c|c|c|c|c|c|}
\hline No. & Variable & 1 & 2 & 3 & 4 & 5 & 6 & 7 & 8 \\
\hline 1 & CHG_PPE $_{t+1}$ & & 0.786 & 0.193 & -0.022 & 0.217 & 0.004 & 0.198 & -0.017 \\
\hline 2 & CAPEX $_{t+1}$ & 0.789 & & 0.197 & 0.004 & 0.196 & 0.039 & 0.168 & -0.108 \\
\hline 3 & Q & 0.199 & 0.188 & & -0.079 & 0.346 & -0.166 & 0.166 & 0.043 \\
\hline 4 & SIZE & -0.050 & -0.017 & -0.092 & & -0.044 & 0.236 & 0.046 & -0.146 \\
\hline 5 & $\mathrm{CF}$ & 0.179 & 0.154 & 0.345 & -0.007 & & -0.350 & 0.192 & 0.150 \\
\hline 6 & LEVERAGE & 0.016 & 0.055 & -0.188 & 0.159 & -0.357 & & 0.113 & -0.209 \\
\hline 7 & SALESGROWTH & 0.177 & 0.154 & 0.158 & 0.012 & 0.179 & 0.074 & & -0.152 \\
\hline 8 & LIQUIDITY & -0.067 & -0.142 & 0.055 & -0.122 & 0.151 & -0.170 & -0.166 & \\
\hline
\end{tabular}

Notes: Table 3 presents the Pearson correlations for the main variables for the full sample (below the diagonal) and the mandatory sample (above the diagonal). Please refer to the Appendix for variable definitions. 
Table 4 - Increase in reporting frequency increases and investment stock price sensitivity

Full sample

(1)

CHG_PPE ${ }_{t+1} \quad$ CAPEX $_{t+1}$

Variable

Q

TREAT x Q

$0.0156^{* * *} \quad 0.0105 * * *$

(0.00346) (0.00237)

$-0.0111^{* *}$

$-0.00723 * *$

(0.00459)

$(0.00315)$

POST x Q

$-0.000331$

0.00001

(0.00325)

TREAT $x$ POST $x$ Q

$0.0145 * * *$

(0.00481)

TREAT $x$ POST

$-0.0236^{* *}$

$(0.00970)$

(0.00236)

0.0104***

(0.00355)

$-0.0139 *$

$(0.00764)$

POST

$-0.0122 *$

$(0.00695)$

$-0.00263$

0.0641

$(0.0553)$

$(0.00556)$

POST x CF

TREAT $x$ POST $x$ CF

CF

SIZE

LEVERAGE

SALESGROWTH

LIQUIDITY

0.0179

(0.0496)

$-0.0993$

$-0.0962$

(0.0628)

(0.0588)

$0.141 * * *$

$0.151 * * *$

(0.0544)

(0.0497)

$-0.0610 * * *$

$-0.0385 * * *$

$(0.00554)$

(0.00466)

$-0.148 * * *$

$-0.108 * * *$

(0.0188)

(0.0148)

$0.0187 * * *$

$0.0112 * * *$

(0.00459)

$(0.00323)$

$0.00652 * * *$

$0.00372 * * *$

(0.00168)

(0.00134)

YES

YES

YES

Industy $\mathrm{x}$ Year

YES

11,364

11,364

0.414

0.534

Mandatory sample

(3)

(4)

CHG_PPE ${ }_{t+1}$ CAPEX $_{t+1}$

$0.0139 * * * \quad 0.0148 * * *$

$(0.00343) \quad(0.00272)$

$-0.0117^{* * *} \quad-0.0126^{* * *}$

$(0.00397) \quad(0.00322)$

$-0.00001 \quad-0.00228$

(0.00414) (0.00373)

0.0129** 0.0122**

(0.00569) (0.00474)

$-0.0234 * * \quad-0.0249 * * *$

(0.0114) (0.00921)

$-0.0182^{*} \quad-0.000584$

$(0.00932) \quad(0.00720)$

$0.147 * * \quad 0.0385$

$(0.0654) \quad(0.0544)$

$-0.100 \quad-0.0348$

$(0.0765) \quad(0.0648)$

$0.143 * * * \quad 0.182 * * *$

(0.0525) (0.0428)

$-0.0533 * * * \quad-0.0330 * * *$

(0.00726) (0.00553)

$-0.132 * * * \quad-0.101 * * *$

(0.0250) (0.0179)

$0.0222 * * * \quad 0.0106 * * *$

$(0.00597) \quad(0.00404)$

$0.0113 * * * \quad 0.00594 * * *$

(0.00248) (0.00193)

YES YES

YES YES

$6,180 \quad 6,180$

$0.427 \quad 0.571$

Notes: This table reports the regression results of Equation (1) for the full sample and the mandatory sample providing evidence of the effect of reporting frequency on IPS. Please refer to the Appendix for variable definitions. ${ }^{*}, * *, * * *$ Denote statistical significance (two-sided) at the 10 percent, 5 percent, and 1 percent levels, respectively. Standard errors, reported in parentheses, are obtained by clustering at the firm level. 
Table 5 - Dynamic timing effect of reporting frequency increases on investment stock price sensitivity

Full sample

(1)

CHG_PPE $_{t+1} \quad$ CAPEX $_{t+1}$

TREAT x POST(-1) x Q

$$
0.00405
$$

$(0.00293)$

TREAT x POST $(+1,+2) \times \mathrm{Q}$

$0.0163 * * *$

$(0.00461)$

TREAT x POST $(+3,+5) \times \mathrm{Q}$
$0.0147 * * * \quad 0.00980 * * *$

$(0.00475) \quad(0.00355)$
Mandatory sample

(3)

(4)

CHG_PPE ${ }_{t+1}$ CAPEX $_{t+1}$

$\begin{array}{cc}0.00523 & 0.00333 \\ (0.00432) & (0.00280) \\ 0.0142 * * & 0.0135 * * * \\ (0.00559) & (0.00465) \\ 0.0129 * * & 0.0118 * * \\ (0.00557) & (0.00470)\end{array}$

YES

YES

YES

YES

YES YES

YES

YES

YES

Observations

11,364

11,364

$0.415 \quad 0.535$

$0.415 \quad 0.535$

6,180

6,180

R-squared

0.572

Notes: This table provide evidence on the timing of the effect of reporting frequency on IPS for both the full sample and the mandatory sample. Please refer to the Appendix for variable definitions. *, **,*** Denote statistical significance (two-sided) at the 10 percent, 5 percent, and 1 percent levels, respectively. Standard errors, reported in parentheses, are obtained by clustering at the firm level. 
Table 6 - Reporting frequency increases, investment stock price sensitivity, and privately informed trading

Panel A: Full sample

\begin{tabular}{|c|c|c|c|c|c|c|c|c|}
\hline & (1) & (2) & (3) & (4) & (5) & (6) & (7) & (8) \\
\hline & HIGH 1-R ${ }^{2}$ & LOW $1-\mathrm{R}^{2}$ & HIGH 1-R ${ }^{2}$ & LOW 1-R ${ }^{2}$ & HIGH ILLIQ & LOW ILLIQ & HIGH ILLIQ & LOW ILLIQ \\
\hline Variable & CHG_PPE $E_{t+1}$ & CHG_PPE $E_{t+1}$ & CAPEX $_{t+1}$ & CAPEX $_{t+1}$ & CHG_PPE $\mathrm{t}_{\mathrm{t}+1}$ & CHG_PPE $E_{t+1}$ & CAPEX $_{t+1}$ & CAPEX $_{t+1}$ \\
\hline \multirow[t]{2}{*}{ Q } & $0.0238 * * *$ & 0.00449 & $0.0141 * *$ & 0.00194 & $0.0302 * * *$ & $0.00840 *$ & $0.0211 * * *$ & 0.00483 \\
\hline & $(0.00595)$ & $(0.00521)$ & $(0.00548)$ & $(0.00358)$ & $(0.00880)$ & $(0.00458)$ & $(0.00612)$ & $(0.00328)$ \\
\hline \multirow[t]{2}{*}{ TREAT x Q } & $-0.0201 * *$ & 0.00219 & -0.00988 & -0.00134 & $-0.0227^{*}$ & 0.00578 & -0.0105 & 0.000545 \\
\hline & $(0.00863)$ & $(0.0114)$ & $(0.00725)$ & $(0.00644)$ & $(0.0131)$ & $(0.00831)$ & $(0.00848)$ & $(0.00565)$ \\
\hline \multirow[t]{2}{*}{ POST x Q } & -0.00908 & $0.0103 *$ & -0.00167 & $0.00714^{*}$ & -0.0124 & 0.00432 & -0.00926 & $0.00509 *$ \\
\hline & $(0.00820)$ & $(0.00531)$ & $(0.00663)$ & $(0.00366)$ & $(0.00963)$ & $(0.00429)$ & $(0.00680)$ & $(0.00307)$ \\
\hline \multirow[t]{2}{*}{ TREAT x POST x Q } & $0.0392 * * *$ & -0.00253 & $0.0242 * * *$ & 0.000582 & $0.0355 * *$ & -0.00692 & $0.0236 * *$ & -0.00294 \\
\hline & $(0.0108)$ & $(0.0108)$ & $(0.00870)$ & $(0.00675)$ & $(0.0164)$ & $(0.00812)$ & $(0.0105)$ & $(0.00576)$ \\
\hline Controls & YES & YES & YES & YES & YES & YES & YES & YES \\
\hline Firm & YES & YES & YES & YES & YES & YES & YES & YES \\
\hline Industry x Year & YES & YES & YES & YES & YES & YES & YES & YES \\
\hline Observations & 4,069 & 4,151 & 4,069 & 4,157 & 4,439 & 4,445 & 4,439 & 4,445 \\
\hline R-squared & 0.558 & 0.606 & 0.649 & 0.716 & 0.511 & 0.560 & 0.613 & 0.690 \\
\hline
\end{tabular}


Panel B: Mandatory sample

\begin{tabular}{|c|c|c|c|c|c|c|c|c|}
\hline \multirow[b]{3}{*}{ Variable } & (1) & (2) & (3) & (4) & (5) & (6) & (7) & (8) \\
\hline & HIGH 1-R ${ }^{2}$ & LOW 1-R ${ }^{2}$ & HIGH 1-R ${ }^{2}$ & LOW 1-R ${ }^{2}$ & HIGH ILLIQ & LOW ILLIQ & HIGH ILLIQ & LOW ILLIQ \\
\hline & CHG_PPE & CHG_PPE & CAPEX $_{t+1}$ & CAPEX $_{t+1}$ & CHG_PPE $E_{t+1}$ & CHG_PPE & CAPEX $_{t+1}$ & CAPEX $_{\mathbf{t}+1}$ \\
\hline \multirow[t]{2}{*}{ Q } & $0.0207 * * *$ & $0.0169 * *$ & $0.0267 * * *$ & $0.0130 * *$ & $0.0244 * * *$ & $0.0148 * *$ & $0.0312 * * *$ & $0.0119 * * *$ \\
\hline & $(0.00644)$ & $(0.00682)$ & $(0.00793)$ & $(0.00508)$ & $(0.00901)$ & $(0.00629)$ & $(0.00725)$ & $(0.00419)$ \\
\hline \multirow[t]{2}{*}{ TREAT x Q } & -0.0111 & -0.0133 & $-0.0164 *$ & -0.0104 & -0.0247 & -0.0101 & $-0.0227 * *$ & -0.00815 \\
\hline & $(0.00787)$ & $(0.0131)$ & $(0.00931)$ & $(0.00979)$ & $(0.0172)$ & $(0.00909)$ & $(0.0113)$ & $(0.00839)$ \\
\hline \multirow[t]{2}{*}{ POST x Q } & -0.00467 & 0.00574 & -0.00750 & 0.000193 & -0.00429 & -0.00186 & -0.0145 & -0.00226 \\
\hline & $(0.00928)$ & $(0.00812)$ & $(0.00974)$ & $(0.00639)$ & $(0.0115)$ & $(0.00677)$ & $(0.00897)$ & $(0.00546)$ \\
\hline \multirow[t]{2}{*}{ TREAT x POST x Q } & $0.0310 * * *$ & 0.00270 & $0.0264 * *$ & 0.00642 & $0.0343 *$ & 0.00541 & $0.0329 * *$ & 0.00499 \\
\hline & $(0.0118)$ & $(0.0133)$ & $(0.0113)$ & $(0.00984)$ & $(0.0200)$ & $(0.0101)$ & $(0.0141)$ & $(0.00928)$ \\
\hline Controls & YES & YES & YES & YES & YES & YES & YES & YES \\
\hline Firm & YES & YES & YES & YES & YES & YES & YES & YES \\
\hline Industry x Year & YES & YES & YES & YES & YES & YES & YES & YES \\
\hline Observations & 2,301 & 2,301 & 2,301 & 2,301 & 2,436 & 2,439 & 2,436 & 2,439 \\
\hline R-squared & 0.570 & 0.659 & 0.679 & 0.739 & 0.509 & 0.589 & 0.610 & 0.736 \\
\hline
\end{tabular}

Notes: This table reports the regression results of Equation (1) for the full sample (Panel A) and the mandatory sample (Panel B) conditional on informativeness of trades. We measure informativeness of trades using 1- $\mathrm{R}^{2}$ and illiquidity (ILLIQ). Firms are split into high and low in terms of the informativeness of trades based on the median values $1-\mathrm{R}^{2}$ and ILLIQ. Please refer to the Appendix for variable definitions. *,**, *** Denote statistical significance (two-sided) at the 10 percent, 5 percent, and 1 percent levels, respectively. Standard errors, reported in parentheses, are obtained by clustering at the firm level. 
Table 7 - Increases in reporting frequency and future profitability

\begin{tabular}{|c|c|c|c|c|c|c|}
\hline & \multicolumn{3}{|c|}{ Full Sample } & \multicolumn{3}{|c|}{ Mandatory sample } \\
\hline \multirow[b]{2}{*}{ Variable } & (1) & (2) & (3) & (4) & $(5)$ & (6) \\
\hline & $\mathrm{ROA}[+1]$ & $\operatorname{ROA}[+1,+2]$ & $\mathrm{ROA}[+1,+3]$ & $\mathrm{ROA}[+1]$ & $\mathrm{ROA}[+1,+2]$ & $\mathrm{ROA}[+1,+3]$ \\
\hline \multirow[t]{2}{*}{ TREAT x POST } & $0.00446 *$ & $0.00430 *$ & 0.00358* & $0.00721 * *$ & 0.00592* & 0.00455 \\
\hline & $(0.00232)$ & $(0.00222)$ & $(0.00212)$ & $(0.00353)$ & $(0.00349)$ & $(0.00343)$ \\
\hline \multirow[t]{2}{*}{ POST } & $-0.00398 *$ & $-0.00406^{* *}$ & $-0.00367 * *$ & $-0.00787^{* * *}$ & $-0.00624 * *$ & $-0.00452 *$ \\
\hline & $(0.00215)$ & $(0.00197)$ & $(0.00176)$ & $(0.00299)$ & $(0.00280)$ & $(0.00252)$ \\
\hline \multirow[t]{2}{*}{ SIZE } & $-0.0151 * * *$ & $-0.0171 * * *$ & $-0.0164 * * *$ & $-0.0170 * * *$ & $-0.0203 * * *$ & $-0.0208 * * *$ \\
\hline & $(0.00246)$ & $(0.00230)$ & $(0.00214)$ & $(0.00344)$ & $(0.00344)$ & $(0.00331)$ \\
\hline \multirow[t]{2}{*}{ LEVERAGE } & $-0.0365 * * *$ & -0.0117 & 0.000590 & $-0.0363 * * *$ & -0.00241 & 0.0116 \\
\hline & $(0.00902)$ & $(0.00827)$ & $(0.00803)$ & $(0.0110)$ & $(0.0100)$ & $(0.00943)$ \\
\hline \multirow[t]{2}{*}{ SALESGROWTH } & $0.0160 * * *$ & $0.00871^{* * *}$ & $0.00543 * * *$ & $0.0178^{* * *}$ & $0.00929 * * *$ & $0.00507 * * *$ \\
\hline & $(0.00174)$ & $(0.00144)$ & $(0.00116)$ & $(0.00247)$ & $(0.00202)$ & $(0.00162)$ \\
\hline \multirow[t]{2}{*}{ LIQUIDITY } & $-0.00186^{* * *}$ & $-0.00211^{* * *}$ & $-0.00208 * * *$ & -0.000619 & -0.00111 & $-0.00154 * *$ \\
\hline & $(0.000678)$ & $(0.000606)$ & $(0.000524)$ & $(0.000967)$ & $(0.000818)$ & $(0.000733)$ \\
\hline Firm & YES & YES & YES & YES & YES & YES \\
\hline Industry x Year & YES & YES & YES & YES & YES & YES \\
\hline Observations & 11,362 & 10,854 & 10,283 & 6,177 & 5,794 & 5,401 \\
\hline R-squared & 0.652 & 0.731 & 0.792 & 0.654 & 0.740 & 0.802 \\
\hline
\end{tabular}

Notes: This table reports regression results that provide evidence of the effect of reporting frequency on future profitability. Please refer to the Appendix for variable definitions. *,***** Denote statistical significance (two-sided) at the 10 percent, 5 percent, and 1 percent levels, respectively. Standard errors, reported in parentheses, are obtained by clustering at the firm level. 
Table 8 - Increases in reporting frequency increases, investment stock price sensitivity, and financing constraints Panel A: Full sample

\begin{tabular}{|c|c|c|c|c|c|c|}
\hline \multirow[b]{3}{*}{ Variable } & \multirow{2}{*}{\multicolumn{2}{|c|}{ AGE }} & \multirow{2}{*}{\multicolumn{2}{|c|}{$\underline{\text { SIZE }}$}} & $(5)$ & (6) \\
\hline & & & & & \multicolumn{2}{|c|}{ KZ Index } \\
\hline & CHG_PPE & CAPEX & CHG_PPE & CAPEX & CHG_PPE & CAPEX \\
\hline TREAT x POST x Q (HIGH FC) & $\begin{array}{c}0.00872 \\
(0.00727)\end{array}$ & $\begin{array}{c}0.00446 \\
(0.00573)\end{array}$ & $\begin{array}{c}0.00584 \\
(0.00676)\end{array}$ & $\begin{array}{c}0.00197 \\
(0.00519)\end{array}$ & $\begin{array}{c}0.00138 \\
(0.00616)\end{array}$ & $\begin{array}{l}-0.00135 \\
(0.00493)\end{array}$ \\
\hline TREAT x POST x Q (LOW FC) & $\begin{array}{c}0.0129 * * * \\
(0.00484)\end{array}$ & $\begin{array}{c}0.00905^{* *} \\
(0.00356)\end{array}$ & $\begin{array}{c}0.0134 * * * \\
(0.00477)\end{array}$ & $\begin{array}{c}0.00930 * * * \\
(0.00357)\end{array}$ & $\begin{array}{c}0.0144 * * * \\
(0.00463)\end{array}$ & $\begin{array}{c}0.0110 * * * \\
(0.00365)\end{array}$ \\
\hline Controls & YES & YES & YES & YES & YES & YES \\
\hline Firm & YES & YES & YES & YES & YES & YES \\
\hline Industry x Year & YES & YES & YES & YES & YES & YES \\
\hline Observations & 11,364 & 11,364 & 11,364 & 11,364 & 10,125 & 10,125 \\
\hline R-squared & 0.417 & 0.536 & 0.417 & 0.536 & 0.418 & 0.533 \\
\hline
\end{tabular}


Panel B: Mandatory sample

(1)

\begin{tabular}{|c|c|c|c|c|c|c|}
\hline \multirow[b]{3}{*}{ Variable } & \multirow{2}{*}{\multicolumn{2}{|c|}{$\underline{\mathrm{AGE}}$}} & \multirow{2}{*}{\multicolumn{2}{|c|}{ SIZE }} & (5) & (6) \\
\hline & & & & & \multicolumn{2}{|c|}{$\underline{\text { KZ Index }}$} \\
\hline & $\mathrm{CHG}_{-} \mathrm{PPE}_{\mathrm{t}+1}$ & $\mathrm{CAPEX}_{\mathrm{t}+1}$ & CHG_PPE $E_{t+1}$ & $\mathrm{CAPEX}_{\mathrm{t}+1}$ & CHG_PPE $E_{t+1}$ & $\mathrm{CAPEX}_{\mathrm{t}+1}$ \\
\hline TREAT x POST x Q (HIGH FC) & $\begin{array}{c}0.00448 \\
(0.00934)\end{array}$ & $\begin{array}{c}0.00226 \\
(0.00718)\end{array}$ & $\begin{array}{l}0.000300 \\
(0.00878)\end{array}$ & $\begin{array}{l}-0.000861 \\
(0.00690)\end{array}$ & $\begin{array}{c}0.00677 \\
(0.00735)\end{array}$ & $\begin{array}{c}0.00911 \\
(0.00616)\end{array}$ \\
\hline TREAT x POST x Q (LOW FC) & $\begin{array}{l}0.0133 * * \\
(0.00567)\end{array}$ & $\begin{array}{c}0.0127^{*} * * \\
(0.00482)\end{array}$ & $\begin{array}{c}0.0170 * * * \\
(0.00633)\end{array}$ & $\begin{array}{c}0.0136 * * * \\
(0.00525)\end{array}$ & $\begin{array}{l}0.0130 * * \\
(0.00649)\end{array}$ & $\begin{array}{l}0.0108 * * \\
(0.00536)\end{array}$ \\
\hline Controls & YES & YES & YES & YES & YES & YES \\
\hline Firm & YES & YES & YES & YES & YES & YES \\
\hline Industry x Year & YES & YES & YES & YES & YES & YES \\
\hline Observations & 6,180 & 6,180 & 6,180 & 6,180 & 5,390 & 5,390 \\
\hline R-squared & 0.429 & 0.572 & 0.429 & 0.574 & 0.418 & 0.561 \\
\hline
\end{tabular}

Notes: This table provides evidence of the effect of reporting frequency increases on IPS conditional on financing constraints (FC). FC are measured using firm age, firm size, and $\mathrm{KZ}$ index. We create dummy variables based on the medians of each $\mathrm{FC}$ variable using the period before the treatment year. Coefficient estimates are obtained from a modified version of Equation (1) which allows coefficients to vary across different levels of FC. Panel A (Panel B) reports the results for the full (mandatory) sample. Please refer to the Appendix for variable definitions. *, **, *** Denote statistical significance (two-sided) at the 10 percent, 5 percent, and 1 percent levels, respectively. Standard errors, reported in parentheses, are obtained by clustering at the firm level. 